This is the peer reviewed version of the following article: Grydaki M, Bezemer D. Nonfinancial sector debt and the U.S. Great Moderation: Evidence from flow-of - funds data. Int J Fin Econ. 2019;24:80-96, which has been published in final form at https://doi.org/10.1002/ijfe.1650. This article may be used for non-commercial purposes in accordance with Wiley Terms and Conditions for self-archiving.

\title{
NONFINANCIAL SECTOR DEBT AND THE U.S. GREAT MODERATION: EVIDENCE FROM FLOW-OF-FUNDS DATA
}

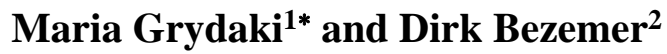 \\ ${ }^{1}$ Division of Economics, University of Stirling, United Kingdom \\ ${ }^{2}$ Faculty of Economics and Business, University of Groningen, The Netherlands
}

\begin{abstract}
In the mid-1980s, two shifts occurred in the US economy: the strong decline of macroeconomic volatility and the strong increase of borrowing by the nonfinancial sector above the level of output growth until 2007. Since access to credit may decrease output fluctuations, we hypothesize that during the Great Moderation borrowing by the nonfinancial sector in excess of GDP growth moderated GDP fluctuations. We estimate GARCH models over 1954-2008 to measure output growth volatility, and run VAR models and a counterfactual simulation in order to analyze the relation of credit growth in excess of output growth and output growth volatility.
\end{abstract}

Key Words: great moderation, credit, VAR, causality

JEL codes: E44, C32, C58

\footnotetext{
* E-mail addresses: maria.grydaki@stir.ac.uk (Maria Grydaki, corresponding author, University of Stirling, FK9 4LA Stirling, Scotland, UK) and d.j.bezemer@ rug.nl (Dirk Bezemer). We thank Wouter den Haan for making the data available and participants at seminars at the Utrecht School of Economics, Groningen University, the $17^{\text {th }}$ International Conference on Macroeconomic Analysis and International Finance in Rethymno, the $1^{\text {st }}$ International $\mathrm{PhD}$ Meeting in Economics in Thessaloniki, and the $28^{\text {th }}$ Annual Congress of the European Economic Association in Gotheborg. Their helpful remarks improved earlier version of this paper. The Institute for New Economic Thinking generously supported this work under grant INO11-00053. Any errors are ours.
} 


\section{NONFINANCIAL SECTOR DEBT AND THE U.S. GREAT MODERATION: EVIDENCE FROM FLOW-OF-FUNDS DATA}

\section{Introduction}

This paper finds that credit growth in the U.S. nonfinancial sector in excess of output growth was among the causal factors of the decline in output volatility during the Great Moderation. In the mid-1980s, two shifts occurred in the US economy. The first was that borrowing by the nonfinancial sector increased strongly within a few years, to a level that was structurally above the level of output growth. It remained high for over two decades, until the 2007 crisis. The second was that macroeconomic volatility declined strongly within a few years. This 'Great Moderation' era saw declines in the volatility of a number of macroeconomic variables in the U.S., as in many other countries (Bernanke, 2004; Cecchetti and Krause, 2006; Ćorić, 2012). The standard deviation of U.S. quarterly growth and inflation declined by half and by two thirds since 1984, respectively (Blanchard and Simon, 2001; Carlstrom et al., 2009). Stock and Watson (2002) find that the standard deviation of U.S. GDP growth declined from 2.6-2.7\% in the 1970s and 1980s to $1.5 \%$ in the 1990s. Also employment volatility strongly declined (Kim and Nelson, 1999; Warnock and Warnock, 2000). The 'Great Moderation' lasted for more than two decades, until the 2007 crisis. Access to credit may decrease output fluctuations since "credit demand appears to contain a significant countercyclical component, which arises from the desire of households and firms to smooth the impact of cyclical variations in income on spending or production" (Bernanke and Gertler, 1995:44).

In this paper we pursue this explanation. We use the ' $Z$ ' tables of the U.S. flow of funds statistics to observe borrowing by the nonfinancial sector in excess of growth. We so obtain a measure for the growth in indebtedness (i.e., in the debt-to-income ratio) of the nonfinancial sector at the macro level, which we link to output volatility at the macro level. We hypothesize that this 'excess' credit growth in the nonfinancial sector was among the Granger-causal factors of the lower volatility of output during the Great Moderation. It bears emphasis that rather than "true causality", we test for Granger causation, which implies that " [t]he cause contains information about the effect that is unique, and is in no other variable is informative on sequence in time", as Granger (2003) himself mentioned in his Nobel acceptance speech. Granger 
continued to say that "[a]t that time, I had little idea that so many people had very fixed ideas about causation, but they did agree that my definition was not "true causation" in their eyes, it was only "Granger causation". I would ask for a definition of true causation, but no one would reply." (Granger, 2003:366). Our hypothesis is related to a number of financial-sector explanations of the Great Moderation, and consistent with a wider literature on credit and macro volatility. But we break new ground in two areas.

First, no study to date has directly analyzed the link between output volatility during the Great Moderation and borrowing by the nonfinancial sector - that is, excluding borrowing for investment in the 'finance, insurance and real estate' sectors (or 'FIRE' sectors, in the classification of the National Income and Product Accounts). A number of studies have focused on FIRE-sector wealth buildup resulting from financial innovations and its possible effect on output volatility moderation, through a wealth effect on income (e.g. Den Haan and Sterk, 2011). The channel through which debt-financed wealth accumulation affects output volatility is different from the effect of debt-financed activity, which we analyze.

A second contribution is that we observe not just credit flows (as other studies do), but the growth in borrowing by the nonfinancial sector in excess of output growth. We so focus on the growth in the debt-to-GDP ratio that is due to borrowing by the nonfinancial sector. This goes beyond simply testing for the effect of credit on output volatility. Other studies have shown that credit flows to the nonfinancial sector normally move together with output growth (Werner, 1997, 2005; Biggs et al., 2010; Board, 2012), and that credit moderates industrial output volatility (Larrain, 2006). A special feature of the Great Moderation was that growth in credit flows to the nonfinancial sector structurally exceeded nominal GDP growth (as we show in the next section) - even when excluding the growth in credit statistically recorded as going to finance, insurance and real estate (i.e. not to the nonfinancial sector), where most of the credit growth was occurring. Plausibly, credit growth in the nonfinancial sector has a more direct impact on output volatility. This has not been analyzed to date. Isolating the effect of credit growth from the effects of other macro developments, which are likely to be correlated with credit growth, is beyond the scope of this paper.

Our empirical approach is to first estimate the conditional standard deviation of output growth as a measure of output volatility. We then estimate a number of reduced-form VAR models over 1984Q1-2008Q1 (the results are robust to variations in the time bounds of the Great Moderation). We examine lags of excess credit growth in a system of equations with (obtained) 
real output growth volatility, the inflation rate and the federal funds rate. We find robust evidence that the increased growth of borrowing beyond GDP growth was a Granger-causal factor in the greater macroeconomic tranquility that characterized the Great Moderation. We then ask if this was also the case before the Great Moderation. In an analysis of a 1954Q3-1978Q4 sample (i.e. one which ends well before the earliest dating of the Great Moderation), we fail to find Granger causality between 'excess' credit growth and output volatility. This may be either because excess credit growth was much smaller before the Great Moderation, as we document, or because the dependence of output volatility on excess credit growth was lower. In either case, there is evidence that the rate of borrowing in the nonfinancial sector beyond GDP growth was a Grangercausal factor in greater macroeconomic tranquility of the Great Moderation, which it was not before.

The paper is organized as follows. The next section motivates our argument with trends in U.S. credit market instruments and in output growth, and makes connections to the literature. In section 3 we present the methodology. Section 4 presents the data and reports results. Section 5 concludes with a summary, reflections and suggestions for future research.

\section{Trends and Argument}

Figure 1 shows the long-term development of the growth in credit in the U.S. The stock of credit (comprising both bank and nonbank lending) relative to GDP quadrupled from 1952 to 2008. Most of that growth occurred during the Great Moderation and credit flows to the finance, insurance and real estate sectors accounted for most of the increase. By the end of the Great Moderation, credit to the finance, insurance and real estate sectors had increased from $30 \%$ of GDP in 1952 (the start of the data series) to 81\% of GDP in 1984, to 260\% of GDP in 2008. Most of this rise, in turn, was due to growth in mortgage debt. After the Great Moderation, FIRE-sector debt dropped sharply relative to GDP. Also credit to the nonfinancial sector (that is, credit to nonfinancial business, to government and nonmortgage credit to households) rose strongly during the Great Moderation: from 87\% of GDP in 1952 to $99 \%$ in 1984 and to $143 \%$ of GDP in 2008. This implies a more than threefold rise in the annual growth rate of the (nonfinancialsector) credit-to-GDP ratio, from $0.4 \%$ in $1952-1983$ to $1.4 \%$ annually over $1984-2008$. Figure 2 plots the growth in credit to the nonfinancial sector and the growth in nominal GDP. We 
compute the difference between the two growth rates and label this variable "excess credit growth".

\section{[Figure 1 HERE]}

[Figure 2 HERE]

The Federal Reserve notes in its 'Guide to the Flow of Funds' that "over long periods of time there has been a fairly close relationship between the growth of debt of the nonfinancial sector and aggregate economic activity" (Board, 2012:176). This is not surprising. As explained by Werner (1997, 2005, 2012), the growth in nonfinancial sector borrowing creates purchasing power which adds proportionally to GDP, because "loans cause deposits and those deposits cause an expansion of GDP transactions" (Caporale and Howells, 2001) - at least if those deposits are expended on goods and services rather than assets (also Minsky, 1982). The empirical literature on credit and growth also emphasizes the role of credit to nonfinancial business rather than a total-credit measure (Levine, 2004; Ang, 2008). This close correspondence between credit to nonfiancial business and value-added growth of goods and services is apparent in the flat part of the graph in Figure 1 on the left, before the Great Moderation.

In contrast, around the start of the Great Moderation, the growth in the stock of credit to the nonfinancial sector exceeds the growth in nominal GDP. The difference, which remained positive for most of the Great Moderation, indicates borrowing which is (by definition) not itself expended on domestic goods and services - if it was, this would have raised GDP growth to the level of credit growth.

Figure 3 plots the cumulative difference between the growth rates of nominal GDP and credit to the nonfinancial sector. This "excess credit growth" cumulation was mostly negative between 1952 and 1970, when the economy was growing faster, on average, than the growth of lending to the nonfinancial sector, due to productivity gains. Through the 1970 s cumulative "excess credit growth" remained at a positive but fairly constant and low level. It took off in the early 1980s and remained high (and increasing in most years) during the Great Moderation.

\section{[Figure 3 HERE]}

There are several ways in which nonfinancial-sector debt growth can rise above GDP growth, and so deviate from the long-term parity noted in the Flow of Funds guide; for instance, by debt- 
financed financial asset acquisition. There is extensive evidence (e.g. Krippner, 2005), that during the Great Moderation households and nonfinancial firms increasingly realized their returns in financial transactions, which financed consumption or investment. Examples include mortgage borrowing followed by house price increases and home equity withdrawal financing household consumption, or business borrowing to repurchase own stock. Lazonick (2011) presents data on 373 companies in the S\&P 500 Index in January 2008 that were publicly listed in 1990. He shows that they expended an annual average of $\$ 106.3$ billion (or $\$ 285$ million per company) on stock repurchases in 1995-1999, up from $\$ 25.9$ billion in repurchases (or $\$ 69$ million per company). This was equal to $44 \%$ of their combined net income (up from 23 percent of their combined net income in 1990-1994). Combined, the 500 companies in the S\&P 500 Index in January 2008 repurchased \$489 billion of their own stock in 2006, representing 62 percent of their net income, and $\$ 595$ billion in 2007, representing 89 percent of their net income. Lazonick (2011) also notes the dramatic increase in stock repurchases after 2003, which may be linked to the upswing in excess credit after 2003 observable in Figure 3.

If consumption or investment out of debt-financed net financial asset acquisition by the nonfinancial sector occurs in countercyclical manner, this might help "households and firms to smooth the impact of cyclical variations in income on spending or production" (Bernanke and Gertler, 1995:44) and so stabilize GDP in the Great Moderation. The testable implication we test in the next sections is that there was Granger causality from this 'excess credit growth' measure to the lower volatility of output growth during the Great Moderation, different from the preGreat Moderation years.

Thus, the present paper's focus is on growth of debt issued to finance nonfinancial-sector activity, rather than financing asset and property market transactions, as in much of the other literature (e.g. Den Haan and Sterk, 2011). Plausibly, credit growth in the nonfinancial sector which was very large, as we just discussed - has a direct and dampening impact on output volatility. This hypothesis is in line with a large literature on credit and volatility, which we now briefly disucss.

That credit stabilizes output is no new finding. We already noted studies by Bernanke and Gertler (1995) on the countercyclical tendency of consumer credit and by Larrain (2006) on the stabilizing properties of credit with respect to industrial output. Iacoviello (2005) estimates a monetary business cycle model with nominal loans and finds that "nominal debt dampens supply shocks, stabilizing the economy under interest rate control" (Iacoviello, 2005:739). Jermann and 
Quadrini (2006) similarly show in a general equilibrium model how innovations in financial markets can generate a lower volatility of output, together with a higher volatility in the financial structure of firms. "Credit View" literature (Bernanke and Blinder, 1988; Bernanke, 1993; Bernanke and Gertler, 1995) and accelerator models (Kiyotaki and Moore, 1997; Campbell, 2005) theorize how the credit system may either amplify or dampen exogenous shocks. A broader strand of literature connects credit conditions to the business cycle and the economy's volatility (e.g. Bliss and Kaufmann, 2003; Mendicino, 2007; Ma and Zhang, 2016), making the general point that financial development tends to stabilize growth (Easterly et al., 2000). Specific to the Great Moderation, Davis and Kahn (2008) find that an important part of the decline in macro volatility is explained by changes in aggregate volatility in the durable goods sector, but without a decline in the uncertainty of incomes. This is understandable if part of durable goods consumption was financed with debt, not income. Their finding is consistent with the greater credit availability that was typical of the Great Moderation (as also Dynan et al., 2006 document), which would also have the effect of loosening the link between the dynamics of income and consumption. Financial innovations and deregulations of lending practices and loan markets during the Great Moderation such as relaxed collateral constraints, lower down payments, and lower rates of amortization for durable goods purchases on household borrowing (Campbell and Hercowitz, 2005) affected consumer spending, housing investment, and business fixed investment (Dynan et al., 2006; Guerron-Quintana, 2009).

Other possible causes for the Great Moderation include better inventory management (McConnell and Perez-Quiros, 2000; Kahn et al., 2002; McCarthy and Zakrajsek, 2007), labor market changes and demography (Jaimovic and Siu, 2009), oil shocks (Nakov and Pescatori, 2010), changed responses to those and other shocks (Gambetti et al., 2008) or broader factors such as institutions (Acemoglou et al., 2003; Owyang et al., 2007), external balances (Fogli and Perri, 2006), the size of the economy (Canning et al., 1998), and development levels (Acemoglu and Zilibotti, 1997; Easterly et al., 1993)- or simply to "good luck" (Ahmed et al., 2002; Cogley and Sargent, 2005; Primiceri, 2005; Sims and Zha, 2006; Benati, 2008; Gambetti et al., 2008; Benati and Surico, 2009). Part of the moderation in output volatility may be also be due to changing responses to monetary shocks (Clarida et al., 2000) and improvements in monetary policy (Bernanke, 2004; Lubik and Schorfheide, 2003; Boivin and Giannoni, 2006; Akram and Eitrheim, 2008). 
Thus our hypothesis is new to the Great Moderation literature. Given present, post-crisis heightened concerns about debt growth (e.g., Mian et al., 2013; IMF, 2012, 2016), it appears timely to rethink the drivers of the Great Moderation - perhaps a time when 'stability was destabilizing (Minsky's (1982), as noted above.

\section{Methodology}

Output growth volatility may be measured by the conditional variance estimated in univariate or multivariate GARCH models (Bollerslev, 1986 based on Engle's (1982) ARCH model; Engle and Kroner, 1995). An analytical survey of multivariate GARCH models is in Bauwens et al. (2006). To obtain volatility estimates, we first test for the existence of ARCH effects (i.e. volatility clustering), which causes volatility levels to correlate positively over time and suggest the estimation of an $\mathrm{ARCH}(\mathrm{p})$ model (Engle, 1982). Nelson and Cao (1992) provide analytically the inequality constraints for univariate GARCH models.

Given the existence of ARCH effects, it is often useful to estimate the more parsimonious GARCH model (Bollerslev, 1986) which allows for a flexible lag structure. In our case also a number of $\mathrm{ARCH}$ models has been estimated but GARCH models performed better. A $\operatorname{GARCH}(\mathrm{p}, \mathrm{q})$ model accommodates autoregressive as well as moving-average components in the heteroskedastic variance.

Because of the squared lagged error term in the $(\mathrm{G}) \mathrm{ARCH}$ specification, the conditional variance is a function of the magnitudes of lagged residuals, but not of their signs. This implies a symmetric response of volatility to positive and negative shocks). In reality, a negative shock ("bad" news) tends to increase volatility more than a positive shock ("good" news) of the same magnitude, especially in financial time series. Accounting for this asymmetric responses (or 'leverage effect'), we estimate two asymmetric specifications for the conditional variance, both widely used. The first is the Exponential GARCH (EGARCH) model (Nelson, 1991) which does not require non-negativity constraints. The conditional variance is in log-linear form $\left(\ln \left(\sigma_{t}^{2}\right)\right)$. So regardless of the magnitude of $\ln \left(\sigma_{t}^{2}\right)$, the implied value of $\sigma_{t}^{2}$ is non-negative. It is therefore possible for the coefficients to take negative values. Also, instead of using the value of the squared lagged innovation term, $\varepsilon_{t-i}^{2}$, the EGARCH model uses the standardized value of $\varepsilon_{t-i}$. Another option is to estimate a general form of the Threshold ARCH model (Zakoian, 1994), which is the Threshold GARCH (or TGARCH) model (Glosten et al., 1993). The TGARCH 
model has an additional term accounting for possible asymmetries. If the asymmetric term is positive, then negative shocks will have larger effects on volatility than positive shocks. If the asymmetric term is different from zero, then there is a threshold effect.

Once we obtain an estimate for output volatility (i.e. the conditional standard deviation), we move on to the aim of this paper, which is to analyze Granger causality between output volatility and other variables in a Vector Autoregressive (VAR) model. Since we have no prior on causality, we assume no exogenous shocks and thus, we opt not to estimate a structural VAR. All variables are treated as endogenous, allowing the value of a variable to depend on its own lags and on the lags of all the other variables in the model. The VAR specification is:

$$
y_{t}=\mathrm{A}_{0}+\mathrm{A}_{1} y_{t-1}+\ldots+\mathrm{A}_{p} y_{t-p}+\varepsilon_{t}
$$

where $y_{t}$ is an ( $\left.\mathrm{n} \times 1\right)$ vector with the $\mathrm{n}$ variables included in the VAR (endogenous variables), $A_{0}$ reflects an (n x 1) vector of intercept terms, $A_{i}$ denote ( $\mathrm{n} \times \mathrm{n}$ ) matrices of coefficients (with $i=1, \ldots p)$ and $\varepsilon_{t}$ is an ( $\left.\mathrm{n} \times 1\right)$ vector of error terms.

We then conduct Granger causality tests (Granger, 1969) and estimate impulse response functions (IRFs). IRFs represent the moving average evolution of the system, describing how one variable responds to a shock to itself or other variables. Sims (1980) suggests that examining IRFs might be the most effective way of exploring Granger causality in multivariate frameworks. We note that while Granger causation is not identical to economic causation - especially not in the case of forward-looking agents taking out credit -it is one of the ways to assess evidence for economic causation which is open to us in the context of this model. We compute orthogonalized impulse responses using Cholesky decompositions (Sims, 1980). IRFs trace the effect of a 1 standard deviation shock to one of the innovations (error terms) on current and future values of the endogenous variables. A shock to the $i^{\text {th }}$ variable is so transmitted to the other endogenous variables in the VAR system as well as the $\mathrm{i}^{\text {th }}$ variable itself. Another way to do this is to characterize the dynamic behavior of the VAR in a forecast error variance decomposition analysis. And third, we present a counterfactual analysis.

\section{Data and Empirical Results}

The variables included in the model are (i) the logarithm of real GDP (RGDP), (ii) excess credit growth (EXCRED), the difference between the growth rates of nominal credit to the nonfinancial sector and nominal output, (iii) the logarithm of the (overnight) federal funds rate (FR), and (iv) 
inflation (INF) measured by the real GDP deflator. ${ }^{1}$ We refer to Appendix A for details of the construction of EXCRED. With these four variables in a VAR framework, we control for the stance of monetary policy, for inflation, and for the endogeneity of credit to growth.

We use quarterly data for the U.S. over two subsamples, 1954Q3-1978Q4 (before the Great Moderation) and 1984Q1-2008Q1 (during the Great Moderation). We applied the Chow test for structural breaks over the whole period 1954Q3-2008Q1 and found that any quarter in 1980Q11983Q4 is a potential breakpoint in output volatility. This is consistent with Boivin and Giannoni (2006) who report that there is no robust breakpoint at which the Great Moderation would have started. Fang and Miller (2008) show that the time-varying variance of output falls sharply or even disappears once they incorporate a one-time structural break in the unconditional variance of output starting 1982 or 1984 . To test sensitivity to choice of break point, we chose 1981Q2 as alternative breakpoint and we re-estimated the VAR. The results are similar to those obtained for the periods 1954Q3-1978Q4 and 1984Q1-2008Q1 and are available upon request.

We follow the convention in the Great Moderation literature, where 1984 is often adopted as the start of the Great Moderation (among others Kim and Nelson, 1999; McConnell and PerezQuiros, 2000; Kahn et al., 2002; Stock and Watson, 2002), though other years in the early 1980s are also used. We conducted an extensive break point robustness analysis by letting the data select break points independently of the Great Moderation dating. This did not change the findings reported below, so that we are confident our results are not driven by the choice of break points. We checked for multiple unknown breaks in the credit data during the entire sample using the Bai-Perron (Bai and Perron, 1998, 2003) procedure. Four breaks were detected (1967Q2, 1975Q1, 1990Q4 and 1998Q2); in addition, there are multiple break points in the output growth series: 1967Q2, 1975Q1, 1982Q3 (the Great Moderation start), 1990Q4, 1998Q2 and 1999Q4. We then conducted the analysis using these break points. The results in and before the Great Moderation are consistent with the results reported in this paper, which adopts break point consistent with the dating of the Great Moderation in the literature. That is, our results are not driven by the choice of break points.

Two of the four endogenous variables, the logarithms of RGDP and FR, are detected to be stationary when taking their first difference (I(1)) in both subsamples, while the other two endogenous variables, EXCRED and INF, are found to be stationary at their level (I(0)). We

\footnotetext{
${ }^{1}$ We thank Wouter den Haan for making the data available; see Den Haan and Sterk (2011).
} 
apply the following stationarity tests to the logs of the variables: (i) Kwiatkowski-PhillipsSchmidt-Shin (KPSS) (Kwiatkowski et al., 1992), (ii) Augmented Dickey-Fuller (ADF) (Dickey and Fuller, 1979) and (iii) Phillips and Perron (PP) (Phillips and Perron, 1988). For tests (i) and (iii), the lag length was selected by the kernel-based estimator of the frequency zero spectrum, which is based on a weighted sum of the covariances. For test (ii) the selection of the number of lags in the test equations is according to the Schwartz Information Criterion (SIC). Stationarity is tested at $1 \%, 5 \%, 10 \%$ significance levels and the time trend has been taken into account in the test equation. Unit root test results are available on request.

After testing for stationarity, we examine the presence of $\mathrm{ARCH}$ effects (clustered volatility) by conducting the ARCH Lagrange Multiplier (ARCH-LM) test, for 1 to 12 lags (Engle, 1982). Table 1 reports descriptive statistics and values of the ARCH-LM statistic for the two subsamples.

\section{[Table 1 HERE]}

All variables have positive growth rates (differenced logs) on average. All variables tend to be more volatile before the beginning of the Great Moderation than during the Great Moderation. The distribution of inflation exhibits positive skewness with few high values in both subsamples; the opposite holds for the remaining variables. Further, the kurtosis (or "peakedness") statistics for the distributions of all the variables show more deviations from the normal distribution in the first subsample than in the second. The ARCH-LM test shows evidence of ARCH effects in the squares of real output growth rate in both subsamples. We only test for ARCH effects in real GDP growth as we are interested in its volatility and not in the volatility of the other variables

We estimate four (symmetric and asymmetric) GARCH models in order to obtain the conditional standard deviation of RGDP, accounting for autoregressive terms. We first select the models which meet the non-negativity constraints and stationarity conditions (in the symmetric GARCH models), and/or which support the existence of leverage or threshold effect (in the asymmetric GARCH models). Table 2 reports the three AR-GARCH models that pass the above tests. From this subset, the preferred GARCH model is selected according to the minimum value of the Schwarz Information Criterion (SIC). We used 1-12 lags for the estimation of the AR(p)(A)Symmetric GARCH models. Three models meet the criteria of nonnegativity constraints on the conditional variance coefficients (apart from EGARCH model for which such restrictions are not necessary) and residual diagnostics of no remaining $\mathrm{ARCH}$ effects and remaining 
autocorrelation. The SIC value indicates that the conditional variance of output growth (and subsequently the conditional standard deviation) is best captured by a symmetric GARCH model - specifically, the AR(2)-GARCH(1,1). Several conditional variance specifications have been estimated and the GARCH(1,1) performs better. The Ljung-Box statistic indicates that the estimated model is well-specified once it does not suffer from remaining autocorrelation $(\mathrm{Q}(\mathrm{p}))$ and remaining $\mathrm{ARCH}$ effects $\left(\mathrm{Q}^{2}(\mathrm{p})\right)$.

\section{[Table 2 HERE]}

Having obtained the conditional standard deviation estimates for the volatility of real output growth, we then estimate a number of reduced-form VAR models on quarterly data for the two subsamples 1954Q3-1978Q4 and 1984Q1-2008Q1. We examine whether lags of excess credit growth $\left(\right.$ EXCRED) matter to the volatility of real output growth (denoted $\left.\sigma_{\mathrm{dlrgdp}}\right)$. Other variables in the system are the inflation rate (INF) and the change in the log of federal funds rates (FR), as in Den Haan and Sterk (2011). We estimate $\operatorname{VAR}(p)$ models with $p=1, \ldots 12$. The model selection criterion is again the minimum SIC value. ${ }^{2}$ This procedure yields a VAR(1) model for both subsamples. Although the lag order of the VAR is short, the dynamic behavior of the variables can be captured sufficiently in the first subsample. We tried also VAR(2) as indicated by Akaike Information Criterion (AIC); the qualitative results do not change. In the second subsample $\operatorname{VAR}(1)$ is indicated by both information criteria.

After estimating the model, we explore the relationships between the variables in three ways. First, we run Granger causality tests, where a series $x_{t}$ is said to Granger-cause a series $y_{t}$ if changes in $x_{t}$ precede changes in $y_{t}$ so that $x_{t}$ improves predictions of $y_{t}$, but $y_{t}$ does not improve predictions of $x_{t}$ (Granger, 1969). Second, we compute impulse response functions (IRFs) which quantify the effect of a one standard deviation shock to innovations in the error terms of one variable on current and future values of it and all other variables. An IRF graph so displays the response of any variable over time to a shock in its own or other error terms. Sims (1980) suggests that examining IRFs might be the most effective way to observe the presence (or otherwise) of Granger causation in multivariate frameworks. A third way of characterizing the dynamic

\footnotetext{
${ }^{2}$ We estimated the VAR including also output growth. The results do not change qualitatively and are available upon request. We thank an anonymous referee for this suggestion.
} 
behavior of the VAR is to conduct a forecast error variance decomposition analysis, as suggested also by Sims (1980). Granger causality tests are reported in Table 3.

[Table 3 HERE]

We detect, first, unidirectional causality from excess credit growth (EXCRED) to output volatility $\left(\sigma_{\mathrm{dlrgdp}}\right)$ in, but not before the Great Moderation. This is consistent with the hypothesis that during the Great Moderation, borrowing by the nonfinancial sector in excess of GDP growth moderated GDP fluctuations, which it did not before. We also find that changes in interest rates Granger-caused output volatility both before and during the Great Moderation. The Granger causality from interest rates to output volatility is still significant during the Great Moderation but with much lower value for the test statistic, implying a gradual weakening of Granger

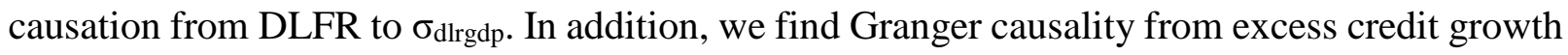
to changes in interest rate in both subsamples. Furthermore, inflation Granger-caused interest rates during the Great Moderation, while interest rates Granger-caused inflation before the Great Moderation. This plausibly reflects the adoption of an inflation target in monetary policy.

Figure 4 shows results from IRF analyses over 12 periods for the two subsamples. Because all four variables are endogenous, we report all IRF graphs in the interest of completeness. There are three significant effects in the IRFs. Most relevant to our hypothesis, we find that a onestandard deviation shock in EXCRED has a negative impact on $\sigma_{\text {dlrgdp }}$ after the second quarter (and with decreasing strength) in the Great Moderation, but not before the Great Moderation. This is consistent with our hypothesis that the rise in excess credit growth is among the causes of the Great Moderation volatility decline - either due to lower excess credit growth, or because the dependence of output volatility on excess credit growth was lower before the Great Moderation.

We also observe that before the Great Moderation, a one-standard deviation shock in DLFR decreases $\sigma_{\text {dlrgdp }}$ significantly during quarters 2-5. During the Great Moderation there is quarters 2 positive and significant response of EXCRED to a one-standard deviation shock in DLFR, and of DLFR to a one-standard deviation shock in INF in period 2.

[Figure 4 HERE] 
The forecast error variance decomposition supports the observations from Granger causation tests (Table 4). We computed the 12-quarter ahead forecast error variance decompositions.18.2\% of output growth volatility during the Great Moderation is attributable to excess credit growth, whereas almost nothing, $0.2 \%$, of it was explained by excess credit growth before the Great Moderation. Conversely, changes in interest rates and inflation both explain substantial parts of output volatility before the Great Moderation, ( $8.8 \%$ and $4.3 \%$ respectively) but much less during the Great Moderation (5.9\% and $0.1 \%$ respectively). ${ }^{3}$

\section{[Table 4 HERE]}

Finally, we also run a counterfactual analysis where we take during-Great Moderation VAR parameter estimates and then apply these to pre-Great Moderation variables values, in order to compute an output volatility forecast in each quarter. We contrast this to actual output volatility forecast during the Great Moderation. This exercise asks how much larger output growth volatility in the Great Moderation would have been, had the relations between excess credit growth and the other variables with output volatility not changed in the way it did. Note that the outcome of this procedure should not be interpreted as strictly isolating the effect of excess credit growth on output volatility. The possible impacts, if any, of the other variables in the system on output volatility are included. That is, in the counterfactual simulation all parameter estimates (not just the excess credit parameter) have counterfactual (pre-Great Moderation) values, since the parameters are estimated in a system. But the Granger test and IRF results suggest that of the four variables, the changes in effect of excess credit on output volatility (both directly and through the other variables) were the most significant. Figure 5 presents the results.

\section{[Figure 5 HERE]}

Figure 5 shows that output growth volatility is 0.0088 on average in the counterfactual simulation, compared to the actual 0.0057 average. This result suggests that actual output growth

\footnotetext{
${ }^{3}$ We note the alternative way to address the ordering of variables in the VAR is to produce Generalized Impulse Response Functions. We thank a referee for suggesting this. These results are different in some cases from the results reported in this paper. The different results obtained with Generalized Impulse Response Functions (GIRF) do not necessarily contradict our results. For instance, they are understandable; GIRF are derived under the assumption of multivariate normality, which might not hold here. We mimicked the advantage of GIRF (it is unaffected by the ordering of variables) by varying the variable ordering. The qualitative results are robust to this. The results for variance decomposition and IRF remain qualitatively the same if we change the order of entering variables in the VAR.
} 
volatility was between a quarter and a third lower than what it would have been, had the relations between excess credit growth and other variables with output growth volatility not changed in the way they did. This reduction in output growth volatility compares to reported declines in the standard deviation of U.S. quarterly growth by up to one half since 1984 (Blanchard and Simon, 2001; Stock and Watson 2002). On this count, the counterfactual simulation results suggest that the present paper identifies a mechanism behind the Great Moderation that is not only statistically significant, but also non-negligible in magnitude.

\section{Summary, Discussion and Conclusions}

In the mid-1980s, two shifts occurred in the US economy. The first was that macroeconomic volatility declined strongly within a few years. This 'Great Moderation' lasted for more than two decades, until 2007. The second was that borrowing by the nonfinancial sector increased strongly within a few years, to a level that was structurally above the level of growth. It remained high for over two decades, until 2007. Since access to credit may decrease output fluctuations, we hypothesize that during the Great Moderation borrowing by the nonfinancial sector in excess of GDP growth moderated GDP fluctuations.

No study to date has directly analyzed the link between output volatility during the Great Moderation and borrowing by the nonfinancial sector. The effect of debt-financed wealth accumulation on volatility is different from the effect of debt-financed activity, which we analyze. A second contribution is that we observe not just credit flows (as most other studies do), but the growth in borrowing by the nonfinancial sector in excess of output growth (or 'excess credit growth'), which captures the growth in indebtedness of the nonfinancial sector.

We show that excess credit growth was persistently positive during most of the Great Moderation, which it was not before. We test the hypothesis that this Granger-caused lower output volatility. We estimate univariate GARCH models in order to obtain estimates for the volatility of output growth. We obtain a VAR model with the volatility of output growth, excess credit and control variables (interest rate and inflation) over two periods, 1954-1978 (before the Great Moderation) and 1984-2008 (during the Great Moderation). Results from Granger causality tests, impulse response functions, forecast error variance decompositions and a counterfactual simulation suggest that excess credit growth was Granger-causing the decline in 
output volatility during the Great Moderation, and that the magnitude of the effect on output volatility was non-negligible.

As to the interpretation of these results, a focus on debt growth is one way to connect (as in Bean, 2011) the Great Moderation to the (2007) 'Great Crash' and the 'Great Recession' that followed. Bean (2011) discusses how low volatility in real and financial variables induced more debt-financed investment and risk taking than would otherwise have occurred in the decades preceding the Crash. This more cautionary view on credit growth also fits in with Minsky's (1982) theory that 'stability is destabilizing', precisely because of the buildup in leverage that it encourages. Kemme and Roy (2012) show that the U.S. mortgage-driven house price boom was a good predictor of the crisis. Cross-country empirical results point in the same direction. Akram and Eitrheim (2008) find that stabilization, not acceleration of credit growth enhances stability in both inflation and output in the long run. Arcand et al. (2012) find that there can be 'too much finance': above a threshold level of the credit-to-GDP ratio, the growth effect of credit declines and turns negative. Cecchetti et al. (2011) likewise conclude that beyond a certain level, debt is a drag on growth. Reinhart and Rogoff (2009) find that a common denominator of financial crisis is a credit boom while Jorda et al. (2012) find that more credit-intensive expansions tend to be followed by deeper recessions and slower recoveries. Schularick and Taylor (2012) also analyze that financial crisis are 'credit booms gone bust'.

In line with these recent studies, this paper motivates a link between Moderation and Crash: perhaps there was a moderation of output volatility partly due to immoderate credit growth not only in mortgage markets but also in the nonfinancial sector. 


\section{Appendix A: Data Construction}

We construct a measure for credit flows which finance activity in the nonfinancial sector. Since a large part of credit flows to the nonfinancial sector are mortgages to households which do not finance activity but finance transactions in real estate assets (Werner 1997, 2005), excluding mortgages is the most significant difference between our measure and other 'credit to the private nonfinancial sector' measures used in the literature (e.g. Beck et al., 2000, updated in Beck et al., 2013). Obviously mortgages also play a role, albeit a different one, in understanding Great Moderation dynamics (Kemme and Roy, 2012; Grydaki and Bezemer, 2013), but they are not the focus of this paper.

We utilize quarterly data from ' $Z$ ' tables in the Flow of Funds Accounts. Net credit to the nonfinancial sector is the difference between stocks of credit market instruments held as assets and as liabilities by the nonfinancial sector. They are recorded in series FL384004005.Q and FL394104005.Q in Z1, respectively. We subtract mortgage credit recorded in series FL383165005.Q, 'domestic nonfinancial sector; total mortgages; liability'. Apart from 'credit market instruments' nonfinancial-sector activity is additionally financed by inter-firm trade credit (FL383070005.Q; see Mateut, 2005 on the role of trade credit), firm-to-customer consumer credit (FL383066005.Q) and 'other loans and advances' (FL383069005.Q). We add these credit stocks (which are quantitatively small relative to the credit market instruments stock). Finally, we subtract net financial investment (including home equity withdrawal; Greenspan and Kennedy, 2008). 


\section{References}

Acemoglou, D. and F. Zilibotti (1997), "Was Prometheus Unbound by Chance? Risk, Diversification, and Growth,” Journal of Political Economy 105: 709-51.

Acemoglou, D., S. Johnson, J. Robinson and Y. Thaicharoen (2003), "Institutional Causes, Macroeconomic Symptoms: Volatility, Crises and Growth,” Journal of Monetary Economics 50: 49-123.

Ahmed, S., A. Levin and B. Wilson (2002), "Recent U.S. Macroeconomic Stability: Good Luck,

Good Policies, or Good Practices?," International Finance Discussion Papers 730, Board of Governors of the Federal Reserve System (U.S.).

Akram, Q. and O. Eitrheim (2008), "Flexible Inflation Targeting and Financial Stability: Is It Enough to Stabilize Inflation and Output?," Journal of Banking and Finance 32: 1242-54.

Ang, J. (2008), "A Survey of Recent Developments in the Literature of Finance and Growth," Journal of Economic Surveys 22: 536-76.

Arcand, J.L., E. Berkes and U. Panizza (2015), “Too Much Finance?,” Journal of Economic Growth 20:105-48.

Bai, J. and P. Perron (1998), "Estimating and Testing Linear Models with Multiple Structural Changes," Econometrica 66: 47-78.

Bai, J. and P. Perron (2003), "Computation and Analysis of Multiple Structural Change Models," Journal of Applied Econometrics 18: 1-22.

Barnett, W. and M. Chauvet (forthcoming), "The End of the Great Moderation? How Better Monetary Statistics Could Have Signaled the Systemic Risk Precipitating the Financial Crisis," Journal of Econometrics Annals.

Bauwens, L., S. Laurent and J. Rombouts (2006), "Multivariate GARCH Models: A Survey," Journal of Applied Econometrics 21: 79-109.

Bean, C. (2011), “Joseph Schumpeter Lecture: The Great Moderation, the Great Panic, and the Great Contraction," Journal of the European Economic Association 8: 289-325.

Beck, T., A. Demirgüç-Kunt and R. Levine (2000), “A New Database on Financial Development and Structure," The World Bank Economic Review 14: 597-605.

Beck, T., A. Demirgüç-Kunt, R. Levine, M. Čihák and E. Feyen (2013), “Financial Development and Structure Dataset (updated April 2013)," 
http://econ.worldbank.org/WBSITE/EXTERNAL/EXTDEC/EXTRESEARCH/0,,content

MDK:20696167 pagePK:64214825 piPK:64214943 theSitePK:469382,00.html

Benati, L. (2008), “The 'Great Moderation' in the United Kingdom," Journal of Money, Credit and Banking 40: 121-47.

Benati, L. and P. Surico (2009), "VAR Analysis and the Great Moderation," American Economic Review 99: 1636-52.

Bernanke, B. (1993), "Credit in the Macroeconomy," Quarterly Review, Federal Reserve Bank of New York issue Spr: 50-70.

Bernanke, B. (2004), "The Great Moderation," Speech at the meetings of the Eastern Economic Association, Washington, D.C., February 20.

Bernanke, B. and A. Blinder (1988), "Credit, Money, and Aggregate Demand," American Economic Review 78: 435-39.

Bernanke, B. and M. Gertler (1995), "Inside the Black Box: The Credit Channel of Monetary Policy Transmission,” Journal of Economic Perspectives 9: 27-48.

Biggs, M., T. Mayer and A. Pick (2010), "Credit and Economic Recovery: Demystifying Phoenix Miracles", SSRN Working Paper.

Blanchard, O. and J. Simon (2001), "The Long and Large Decline in U.S. Output Volatility," Brookings Papers on Economic Activity 1: 135-74.

Bliss, R. and G. Kaufmann (2003), "Bank Procyclicality, Credit Crunches, and Asymmetric Policy Effects: A Unifying Model," Journal of Applied Finance 13: 23-31.

Board (2012), Flow of Funds Guide at http://www.federalreserve.gov/apps/fof/.

Boivin, J., and M. Giannoni (2006), "Has Monetary Policy Become More Effective?," The Review of Economics and Statistics 88: 445-62.

Bollerslev, T. (1986), “Generalized Autoregressive Conditional Heteroskedasticity,” Journal of Econometrics 31: 307-27.

Campbell, J. and Z. Hercowitz (2005), "The Role of Collateralized Household Debt in Macroeconomic Stabilization,” NBER Working Paper No. 11330.

Campbell, S. (2005), "Stock Market Volatility and the Great Moderation," FEDS WP, 2005-47, Board of Governors of the Federal Reserve System.

Canning, D., L.A.N. Amaral, Y. Lee, M. Meyer and H.E. Stanley (1998), "Scaling the Volatility of the GDP Growth Rate," Economics Letters 60: 335-41. 
Caporale, G. and P. Howells (2001), "Money, Credit and Spending: Drawing Causal Inferences," Scottish Journal of Economics 48: 547-57.

Carlstrom, C., T. Fuerst and M. Paustian (2009), "Inflation Persistence, Monetary Policy, and the Great Moderation," Journal of Money, Credit and Banking 41: 767-86.

Cecchetti, A. and S. Krause (2006), "Assessing the Sources of Changes in Volatility of Real Growth," NBER Working Paper No. 11946.

Cecchetti, S., M.S. Mohanty and F. Zampolli (2011), “The Real Effects of Debt,” Bank for International Settlements Working Paper No. 352.

Clarida, R., J. Gali, and M. Gertler (2000), "Monetary Policy Rules and Macroeconomic Stability: Evidence and Some Theory," The Quarterly Journal of Economics 115: 147-80.

Cogley, T. and T. Sargent (2005), "Drifts and Volatilities: Monetary Policy and Outcomes in the Post-WWII US", Review of Economic Dynamics 8: 262-302.

Ćorić, B. (2012), “The Global Extent of the Great Moderation," Oxford Bulletin of Economics and Statistics 74: 493 - 509.

Davis S. and J. Kahn (2008), "Interpreting the Great Moderation: Changes in the Volatility of Economic Activity at the Macro and Micro Levels," Journal of Economic Perspectives 22: 155-80.

Den Haan, W. and V. Sterk (2011), "The Myth of Financial Innovation and the Great Moderation," The Economic Journal 121: 707-39.

Dickey, D. and W. Fuller (1979), "Distribution of the Estimators of Autoregressive Time Series with a Unit Root," Journal of the American Statistical Association 74: 427-31.

Dynan, K., D. Elmendorf and D. Sichel (2006), “Can Financial Innovation Help to Explain the Reduced Volatility of Economic Activity?," Journal of Monetary Economics 53: 123-50.

Easterly, W., M. Kremer, L. Pritchett and L. Summers (1993), "Good Policy or Good Luck? Country Growth Performance and Temporary Shocks," Journal of Monetary Economics $32: 459-83$.

Easterly, W., R. Islam and J. Stiglitz (2000), "Shaken and Stirred: Explaining Growth Volatility," Paper at the 2000 Annual World Bank Conference on Development Economics.

Engle, R. (1982), “Autoregressive Conditional Heteroskedasticity with Estimates of the Variance of United Kingdom Inflation," Econometrica 50: 987-1007.

Engle, R. and K. Kroner (1995), “Multivariate Simultaneous Generalized ARCH,” Econometric Theory 11: 122-50. 
Fang, W. and S. Miller (2008), "The Great Moderation and the Relationship between Output Growth and its Volatility," Southern Economic Journal 74: 819-38.

Fogli, A. and F. Perri (2006), "The "Great Moderation" and the US External Imbalance,” NBER Working Paper No. 12708.

Gambetti, L., E. Pappa, and F. Canova (2008), "The Structural Dynamics of US Output and Inflation: What Explains the Changes?," Journal of Money, Credit, and Banking 40: 369-88. Glosten, L. R., R. Jaganathan, and D. Runkle (1993), “On the Relation between the Expected Value and the Volatility of the Normal Excess Return on Stocks," Journal of Finance 48: 1779-801.

Granger, C. (1969), "Investigating Causal Relations by Econometric Models and Cross-spectral Methods," Econometrica 37: 424-38.

Granger, C. (2003), “Time Series Analysis, Cointegration, and Applications,” Nobel Lecture, Department of Economics, University of California, San Diego, La Jolla, CA 92093-0508, USA.

Greenspan, A. and J. Kennedy (2008), "Sources and Uses of Equity Extracted from Homes," Oxford Review of Economic Policy 24: 120-44.

Grydaki, M. and D. Bezemer (2013), "The Role of Credit in the Great Moderation: A Multivariate GARCH Approach,” Journal of Banking and Finance 37: 4615-26.

Guerron-Quintana, P. (2009), "Money Demand Heterogeneity and the Great Moderation," Journal of Monetary Economics 56: 255-66.

Iacoviello, M. (2005), "House Prices, Borrowing Constraints, and Monetary Policy in the Business Cycle", American Economic Review, 95: 739-64.

IMF (2012), World Economic Outlook, Ch. 3 Dealing with Household Debt, pp. 89-124. Washington, DC: IMF

IMF (2016) Debt: Use it Wisely. October 2016 Fiscal Monitor. Washington, DC: IMF

Jaimovich, N. and H. Siu (2009), "The Young, the Old, and the Restless: Demographics and Business Cycle Volatility," American Economic Review 99: 804-26.

Jermann, U. and V. Quadrini (2006), "Financial Innovations and Macroeconomic Volatility," NBER Working Paper No. 12308.

Jorda, O., M. Schularick and A. Taylor (2012), "When Credit Bites Back: Leverage, Business Cycles, and Crises," Federal Reserve Bank of San Francisco Working Paper No. 2011-27. 
Kahn, J., M. McConnell and G. Perez-Quiros (2002), "On the causes of the increased stability of the U.S. economy," Federal Reserve Bank of New York Economic Policy Review 8: 183-202.

Kemme, D. and S. Roy (2012), "Did the Recent Housing Boom Signal the Global Financial Crisis?," Southern Economic Journal 78: 999-1018.

Kim, C. and C. Nelson (1999), "Has the U.S. Become More Stable? A Bayesian Approach Based on a Markov-Switching Model of the Business Cycle," Review of Economics and Statistics 81: 08-16.

Kiyotaki, N. and J. Moore (1997), “Credit Cycles,” Journal of Political Economy 105: 211-48.

Krippner, G. (2005), “The Financialization of the American Economy," Socio-Economic Review 3.2:173-208.

Kwiatkowski, D., P Phillips, P. Schmidt and Y. Shin (1992), "Testing the Null Hypothesis of Stationarity against the Alternative of a Unit Root," Journal of Econometrics 53: 159-78.

Larrain, B. (2006), “Do Banks Affect the Level and Composition of Industrial Volatility?,” The Journal of Finance 61: 1897-925.

Lazonick, W. (2011), “The Innovative Enterprise and the Developmental State: Toward an Economics of Organizational Success,” Institute for New Economic Thinking Annual 2011 Conference, Bretton Woods, NH April 8-11.

Levine, R. (2004), "Finance and Growth: Theory and Evidence," Handbook of Economic Growth, Aghion, P. and S. Durlauf (eds.), Amsterdam, Elsevier.

Lubik, T., and F. Schorfheide (2003), "Computing Sunspot Equilibria in Linear Rational Expectations Models," Journal of Economic Dynamics and Control 28: 273-85.

Ma, Y. and J. Zhang (2016), "Financial Cycle, Business Cycle and Monetary Policy: Evidence from Four Major Economies," International Journal of Finance and Economics 21: 502-27. Mateut, S. (2005), “Trade credit and monetary policy transmission," Journal of Economic Surveys 19: 655-70.

McCarthy, J. and E. Zakrajsek (2007), "Inventory Dynamics and Business Cycles: What Has Changed?," Journal of Money, Credit and Banking 39: 591-613.

McConnell, M. and G. Perez-Quiros (2000), "Output Fluctuations in the United States: What Has Changed since the Early 1980's," American Economic Review 90: 1464-76.

Mendicino, A. (2007), “Credit Market and Macroeconomic Volatility,” European Central Bank Working Paper No. 743. 
Mian, A., K. Rao and A. Sufi (2013), "Household Balance Sheets, Consumption and the Economic Slump,” The Quarterly Journal of Economics 128: 1687-726.

Minsky, H. (1982), Can “It” Happen Again?: Essays on Instability and Finance, M.E. Sharpe, Armonk, N.Y.

Nakov, A. and A. Pescatori (2010), "Oil and the Great Moderation," The Economic Journal 120: $131-56$.

Nelson, D. (1991), "Conditional Heteroskedasticity in Asset Returns: A New Approach," Econometrica 59: 347-70.

Nelson, D. and C. Cao (1992), "Inequality Constraints in the Univariate GARCH Model," Journal of Business \& Economic Statistics 10: 229-35.

Owyang, M.T., J. Piger and H. Wall (2007), “A State-Level Analysis of the Great Moderation,” Federal Reserve Bank of St Louis, Working Paper No. 003B.

Phillips, P. and P. Perron (1988), "Testing for a Unit Root in Time Series Regression," Biometrika Trust 75: 335-46.

Primiceri, G. (2005), “Time Varying Structural Vector Autoregressions and Monetary Policy,” The Review of Economic Studies 72: 821-52.

Reinhart, C. M. and K. S. Rogoff (2009), This Time It's Different: Eight Centuries of Financial Folly, Princeton: Princeton University Press

Schularick, M. and A. Taylor (2012), "Credit Booms Gone Bust: Monetary Policy, Leverage Cycles, and Financial Crises, 1870-2008," American Economic Review 102: 1029-61.

Sims, C. (1980), “Macroeconomic and Reality,” Econometrica 48: 1-48.

Sims, C. and T. Zha (2006), "Were There Regime Switches in U.S. Monetary Policy?," American Economic Review 96: 54-81.

Stock, J. and M. Watson (2002), "Has the Business Cycle Changed and Why?," NBER Working Paper No. 9127.

Warnock, M. and F. Warnock (2000), “The Declining Volatility of U.S. Employment: Was Arthur Burns Right?,” Board of Governors of the Federal Reserve System, International Finance Discussion Paper No. 677.

Werner, R. (1997), “Towards a New Monetary Paradigm: a Quantity Theorem of Disaggregated Credit, with Evidence from Japan," Kredit und Kapital 30: 276-309.

Werner, R. (2005), New Paradigm in Macroeconomics: Solving the Riddle of Japanese Macroeconomic Performance, Palgrave Macmillan. 
Werner, R. (2012), “Towards a New Research Programme on 'Banking and the Economy' Implications of the Quantity Theory of Credit for the Prevention and Resolution of Banking and Debt Crises," International Review of Financial Analysis 25: 1-17.

Zakoian, J-M. (1994), “Threshold Heteroskedastic Models,” Journal of Economic Dynamics and Control 18: 931-55. 


\section{TABLES AND FIGURES}

Table 1: Descriptive Statistics

\begin{tabular}{|c|c|c|c|c|c|}
\hline & Mean & Std dev. & Skewness & Kurtosis & LM-Statistic \\
\hline \multicolumn{6}{|l|}{ 1954Q3-1978Q4 } \\
\hline Real output (RGDP) & 0.0094 & 0.0109 & -0.3512 & 3.5788 & $33.1762 * * *(12)$ \\
\hline Inflation (INF) & 0.0097 & 0.0064 & 0.8570 & 3.5780 & - \\
\hline Excess credit (EXCRED) & 0.0042 & 0.0380 & -0.4203 & 7.5537 & - \\
\hline Federal funds rate $(F R)$ & 0.0232 & 0.1858 & -1.1955 & 9.2076 & - \\
\hline \multicolumn{6}{|l|}{ 1984Q1-2008Q1 } \\
\hline Real output (RGDP) & 0.0076 & 0.0051 & -0.1665 & 3.2697 & $3.5213 *(1)$ \\
\hline Inflation (INF) & 0.0063 & 0.0024 & 0.6443 & 2.7108 & - \\
\hline Excess credit (EXCRED) & 0.0107 & 0.0352 & -0.4955 & 2.8513 & - \\
\hline Federal funds rate (FR) & -0.0133 & 0.1401 & -0.6680 & 5.9591 & - \\
\hline
\end{tabular}

Note: RGDP is the annual growth rate of the logarithm of RGDP. EXCRED reflects the difference between the growth rates of nominal credit to nonfinancial sector and nominal output. INF and FR are the quarter-on-quarter change in INF and the log of FR, respectively. 
Table 2: AR(p)-(A)Symmetric GARCH Models

\begin{tabular}{|c|c|c|c|}
\hline & AR(2)-GARCH(1,1) & AR(2)-EGARCH(1,1) & AR(2)-TGARCH(1,1) \\
\hline \multicolumn{4}{|c|}{ Conditional Mean Equation } \\
\hline$\mu$ & $\begin{array}{c}0.0080 \\
(0.0000)\end{array}$ & $\begin{array}{c}0.0076 \\
(0.0000)\end{array}$ & $\begin{array}{c}0.0077 \\
(0.0000)\end{array}$ \\
\hline$\varphi_{1}$ & $\begin{array}{c}0.2319 \\
(0.0019)\end{array}$ & $\begin{array}{c}0.2158 \\
(0.0033)\end{array}$ & $\begin{array}{c}0.2209 \\
(0.0042)\end{array}$ \\
\hline$\varphi_{2}$ & $\begin{array}{c}0.1816 \\
(0.0112)\end{array}$ & $\begin{array}{c}0.2099 \\
(0.0034)\end{array}$ & $\begin{array}{c}0.2064 \\
(0.0041)\end{array}$ \\
\hline \multicolumn{4}{|c|}{ Conditional Variance Equation } \\
\hline$\alpha_{0}$ & $\begin{array}{c}2.86 \mathrm{E}-06 \\
(0.2584)\end{array}$ & $\begin{array}{l}-1.0175 \\
(0.0700)\end{array}$ & $\begin{array}{c}3.72 \mathrm{E}-06 \\
(0.2122)\end{array}$ \\
\hline$\alpha_{1}$ & $\begin{array}{c}0.1903 \\
(0.0091)\end{array}$ & $\begin{array}{c}0.3742 \\
(0.0028)\end{array}$ & $\begin{array}{c}0.1053 \\
(0.2710)\end{array}$ \\
\hline$\beta_{1}$ & $\begin{array}{c}0.7823 \\
(0.0000)\end{array}$ & $\begin{array}{c}0.9257 \\
(0.0000)\end{array}$ & $\begin{array}{c}0.7504 \\
(0.0000)\end{array}$ \\
\hline$\lambda_{1}$ & & $\begin{array}{l}-0.1433 \\
(0.0587)\end{array}$ & \\
\hline$\gamma_{1}$ & & & $\begin{array}{c}0.2292 \\
(0.0849)\end{array}$ \\
\hline \multicolumn{4}{|c|}{ Residual Diagnostics } \\
\hline$Q(8)$ & $\begin{array}{l}3.5933 \\
(0.892)\end{array}$ & $\begin{array}{l}4.0708 \\
(0.851)\end{array}$ & $\begin{array}{l}4.5237 \\
(0.807)\end{array}$ \\
\hline$Q^{2}(8)$ & $\begin{array}{l}13.952 \\
(0.083)\end{array}$ & $\begin{array}{l}15.854 \\
(0.045)\end{array}$ & $\begin{array}{l}17.634 \\
(0.024)\end{array}$ \\
\hline$Q(12)$ & $\begin{array}{r}7.3480 \\
(0.834)\end{array}$ & $\begin{array}{l}8.9154 \\
(0.710)\end{array}$ & $\begin{array}{l}9.0317 \\
(0.700)\end{array}$ \\
\hline$Q^{2}(12)$ & $\begin{array}{l}15.769 \\
(0.202)\end{array}$ & $\begin{array}{l}18.199 \\
(0.110)\end{array}$ & $\begin{array}{l}19.469 \\
(0.078)\end{array}$ \\
\hline$S I C$ & -6.7314 & -6.7262 & -6.7198 \\
\hline
\end{tabular}

Notes: The conditional mean equation for the three models is $y_{t}=\mu+\sum_{h=1}^{z} \varphi_{h} y_{t-h}+\varepsilon_{t}, \varepsilon_{t} \mid \psi_{t-1} \sim N\left(0, \sigma_{t}^{2}\right)$ where, $y_{t} \mu, \varphi_{h}, \varepsilon_{t}$ are vectors of the dependent variable, intercept, autoregressive term and the innovation vector, respectively, and $\psi_{t-1}$ is the information set at time $t$ - 1 . In our case $y_{t}$ is output growth. Given an estimate for the conditional mean, we obtain the conditional variance. For the first model the conditional variance is $\sigma_{t}^{2}=\alpha_{0}+\sum_{i=1}^{p} \alpha_{i} \varepsilon_{t-i}^{2}+\sum_{j=1}^{q} \beta_{j} \sigma_{t-j}^{2}$ where $\alpha_{0}$ is the the intercept, $\alpha_{i}$ the 
ARCH terms of the variance equation (with $i=1, \ldots, p$, ) and $\beta_{j}$ denotes the GARCH component parameters. The conditional variance of the second model is given by $\ln \left(\sigma_{t}^{2}\right)=\alpha_{0}+\sum_{j=1}^{q} \beta_{j} \ln \left(\sigma_{t-j}^{2}\right)+\sum_{i=1}^{p} \alpha_{i}\left|\varepsilon_{t-i} / \sigma_{t-i}\right|+\sum_{k=1}^{r} \lambda_{k}\left(\varepsilon_{t-k} / \sigma_{t-k}\right)$. The conditional variance of the third model is given by $\sigma_{t}^{2}=\alpha_{0}+\sum_{i=1}^{p} \alpha_{i} \varepsilon_{t-i}^{2}+\sum_{j=1}^{q} \beta_{j} \sigma_{t-j}^{2}+\sum_{k=1}^{r} \gamma_{k} d_{t-k} \varepsilon_{t-k}^{2}$. The coefficient $\lambda_{1}$ in the $\operatorname{AR}(2)-$ EGARCH(1,1) model, which reflects the asymmetric effect on the conditional variance, is negative supporting the existence of leverage effect. The coefficient $\gamma_{1}$ in the $\operatorname{AR}(2)-\operatorname{TGARCH}(1,1)$ model denotes the asymmetric term in the conditional variance and the positive sign reflects that negative shocks will have larger effects on volatility than positive shocks. Probability values are in parentheses. $\mathrm{Q}(\mathrm{p}), \mathrm{Q}^{2}(\mathrm{p})$ reflect the Ljung-Box statistic for remaining autocorrelation and remaining $\mathrm{ARCH}$ effects, respectively; SIC is the value for Schwarz Information Criterion. 
Table 3: Granger Causality Tests

\begin{tabular}{|c|c|c|}
\hline Testable Hypotheses & Pre-Great Moderation & During-Great Moderation \\
\hline & \multicolumn{2}{|c|}{ Chi-square statistic } \\
\hline & 1954Q3-1978Q4 & 1984Q1-2008Q1 \\
\hline $\begin{array}{l}\text { Excess credit growth }(\text { EXCRED) does not Granger } \\
\text { cause output volatility }\left(\sigma_{\text {dlrgdp }}\right)\end{array}$ & $\begin{array}{c}0.3699 \\
(0.5431)\end{array}$ & $\begin{array}{c}6.1277 \\
(0.0133)\end{array}$ \\
\hline $\begin{array}{l}\text { Output volatility }\left(\sigma_{\text {dlrgdp }}\right) \text { does not Granger cause } \\
\text { excess credit growth }(E X C R E D)\end{array}$ & $\begin{array}{c}0.5543 \\
(0.4566)\end{array}$ & $\begin{array}{c}2.2550 \\
(0.1332)\end{array}$ \\
\hline $\begin{array}{l}\text { Change in federal funds rate }(D L F R) \text { does not } \\
\text { Granger cause output volatility }\left(\sigma_{\text {dlrgdp }}\right)\end{array}$ & $\begin{array}{c}6.5031 \\
(0.0108)\end{array}$ & $\begin{array}{c}3.2901 \\
(0.0697)\end{array}$ \\
\hline $\begin{array}{l}\text { Output volatility }\left(\sigma_{\text {dlrgdp }}\right) \text { does not Granger cause } \\
\text { change in federal funds rate }(D L F R)\end{array}$ & $\begin{array}{c}0.9065 \\
(0.3410)\end{array}$ & $\begin{array}{c}5.8772 \\
(0.0153)\end{array}$ \\
\hline $\begin{array}{l}\text { Inflation }(\text { INF) does not Granger cause output } \\
\text { volatility }\left(\sigma_{\text {dlrgdp }}\right)\end{array}$ & $\begin{array}{c}0.4652 \\
(0.4952)\end{array}$ & $\begin{array}{c}0.1057 \\
(0.7451)\end{array}$ \\
\hline $\begin{array}{l}\text { Output volatility }\left(\sigma_{\text {dlrgdp }}\right) \text { does not Granger cause } \\
\text { inflation }(I N F)\end{array}$ & $\begin{array}{c}0.3841 \\
(0.5354)\end{array}$ & $\begin{array}{c}0.0003 \\
(0.9869)\end{array}$ \\
\hline $\begin{array}{l}\text { Change in federal funds rate (DLFR) does not } \\
\text { Granger cause excess credit growth (EXCRED) }\end{array}$ & $\begin{array}{c}0.5396 \\
(0.4626)\end{array}$ & $\begin{array}{c}0.0301 \\
(0.8622)\end{array}$ \\
\hline $\begin{array}{l}\text { Excess credit growth (EXCRED) does not Granger } \\
\text { cause change in federal funds rate (DLFR) }\end{array}$ & $\begin{array}{c}4.1389 \\
(0.0419)\end{array}$ & $\begin{array}{c}5.9126 \\
(0.0150)\end{array}$ \\
\hline $\begin{array}{l}\text { Inflation (INF) does not Granger cause excess } \\
\text { credit growth (EXCRED) }\end{array}$ & $\begin{array}{c}0.0007 \\
(0.9787)\end{array}$ & $\begin{array}{c}0.6197 \\
(0.4312)\end{array}$ \\
\hline $\begin{array}{l}\text { Excess credit growth (EXCRED) does not } \\
\text { Granger cause inflation (INF) }\end{array}$ & $\begin{array}{l}1.1327 \\
(0.2872)\end{array}$ & $\begin{array}{c}0.7175 \\
(0.3970)\end{array}$ \\
\hline $\begin{array}{l}\text { Inflation (INF) does not Granger cause change in } \\
\text { federal funds rate (DLFR) }\end{array}$ & $\begin{array}{c}0.6649 \\
(0.4307)\end{array}$ & $\begin{array}{c}4.0893 \\
(0.0432)\end{array}$ \\
\hline $\begin{array}{l}\text { Change in federal funds rate (DLFR) does not } \\
\text { Granger cause inflation (INF) }\end{array}$ & $\begin{array}{c}3.3500 \\
(0.0672)\end{array}$ & $\begin{array}{c}0.1686 \\
(0.6814)\end{array}$ \\
\hline
\end{tabular}

Notes: Probability values of the corresponding Chi-square statistics are in parentheses. 
Table 4: Excess credit growth and output volatility: forecast error variance decomposition

\begin{tabular}{lclr}
\hline \multicolumn{4}{c}{$\begin{array}{c}\% \text { of 12-quarters-ahead forecast error variance } \\
\text { of output growth volatility explained by ... }\end{array}$} \\
\hline Before the Great Moderation & \multicolumn{2}{c}{ During the Great Moderation } \\
\hline & $0.2 \%$ & excess credit growth: & $18.2 \%$ \\
excess credit growth: & $8.8 \%$ & change in interest rate: & $5.9 \%$ \\
change in interest rate: & $4.3 \%$ & Inflation: & $0.1 \%$ \\
\hline Inflation: & & & \\
\hline
\end{tabular}


Figure 1: U.S. credit-to-GDP ratios (\%), 1952Q1 - 2012Q1

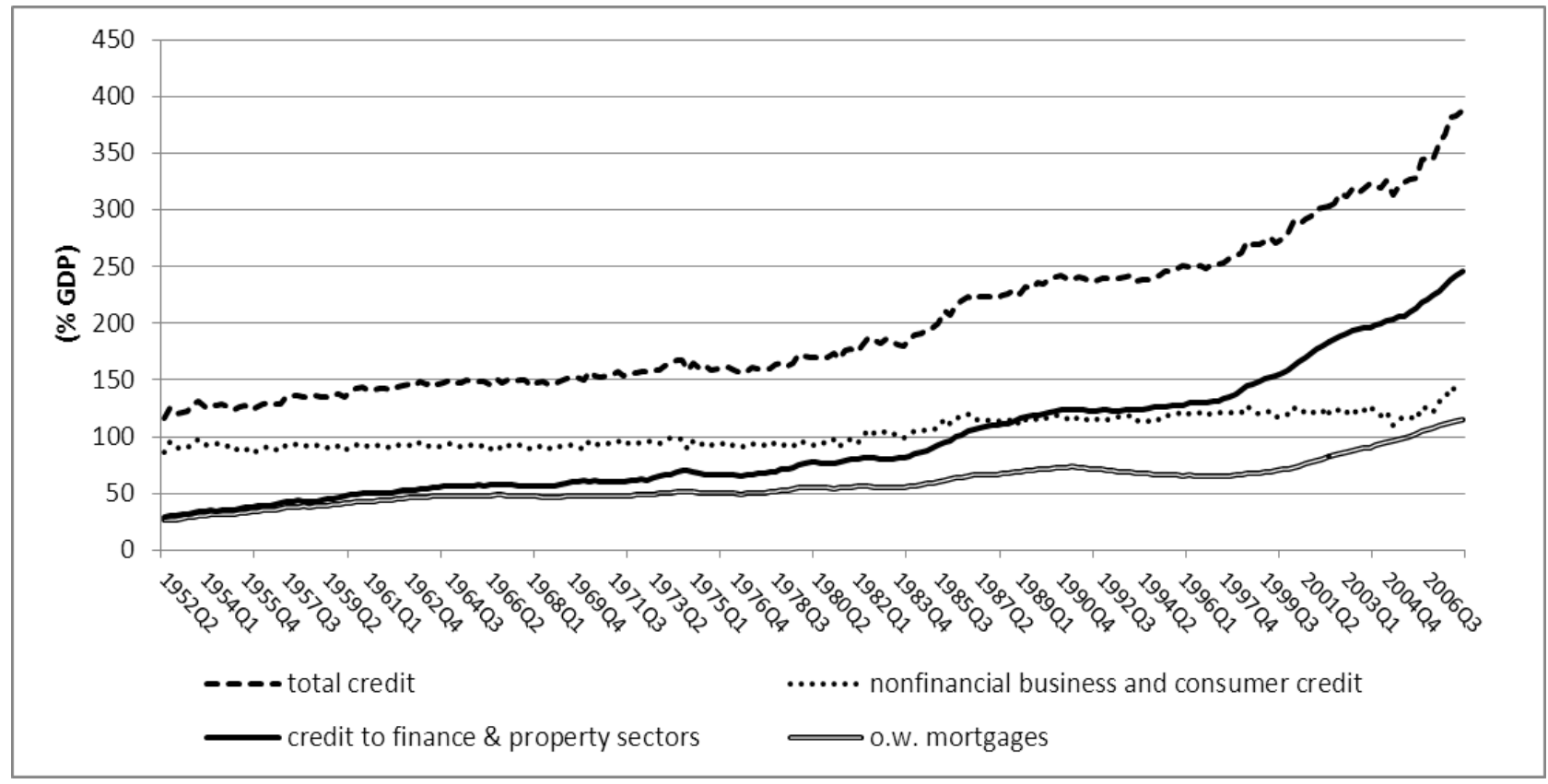

Source: Bureau of Economic Analysis, flow of funds data ( $\mathrm{Z}$ tables).

Figure 2: Credit to the nonfinancial sector and nominal GDP, 1952-2012

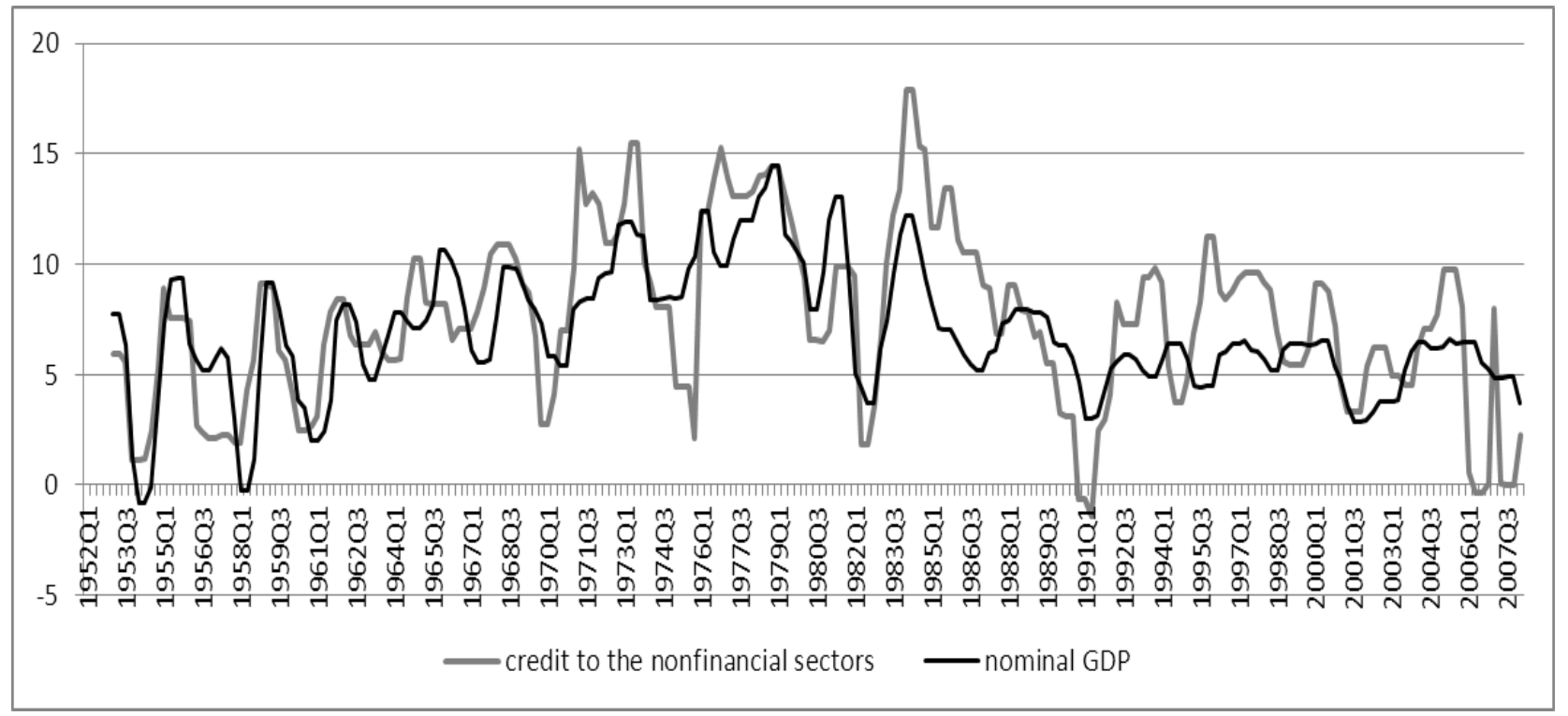


Source: Bureau of Economic Analyis. Note: Data are growth rates (in percent) of nominal Dollar figures. In this graph (but not in the analysis), time series have been smoothed by taking the median of the current, previous and next quarter.

\section{Figure 3: Cumulative percentage point growth of "excess credit", 1952-2008}

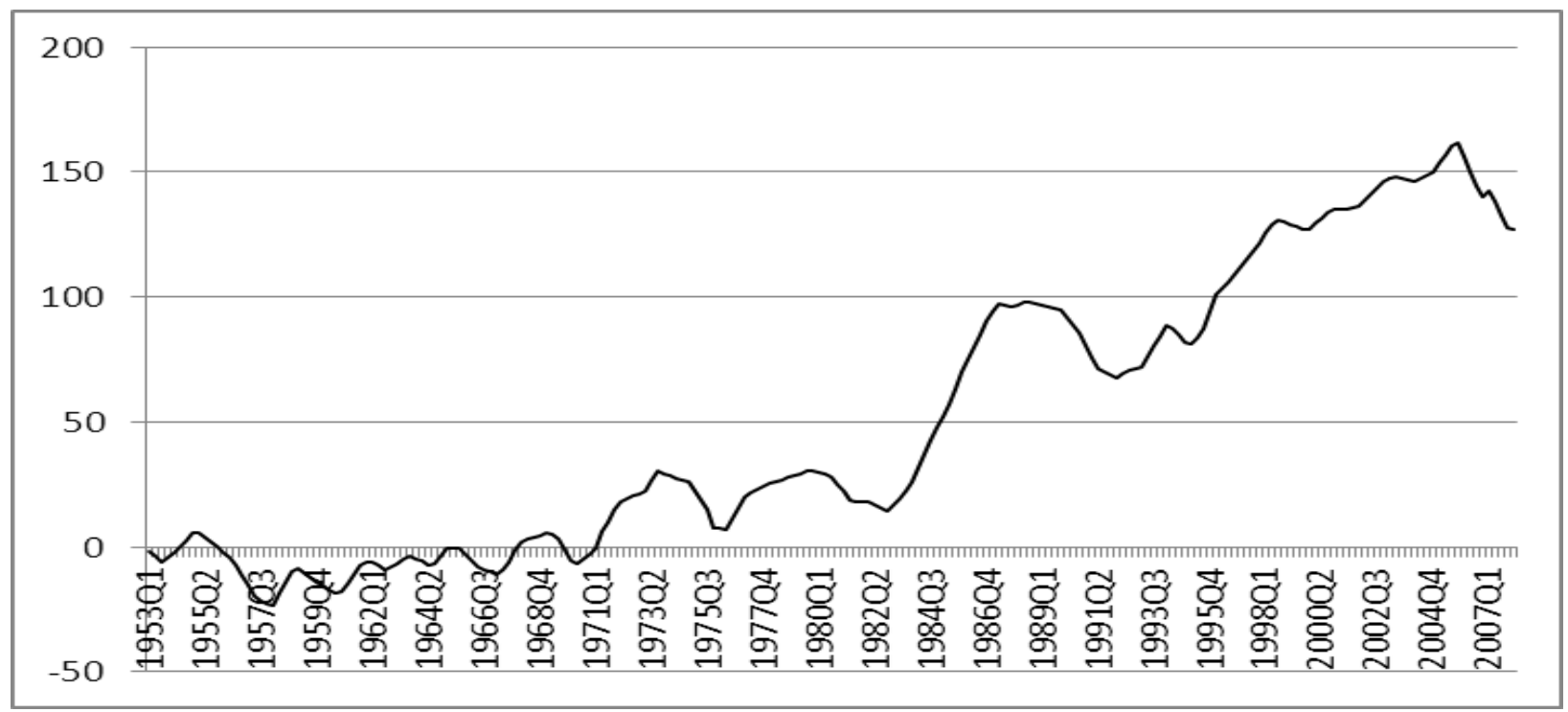

Source: Bureau of Economic Analyis 
Figure 4: Impulse Responses to shocks before (1954Q3 - 1978Q4) and during the Great Moderation (1984Q1-2008Q1)

Response of SDDLRGDP to EXCRED: 1954 Q3 - 1978 Q4

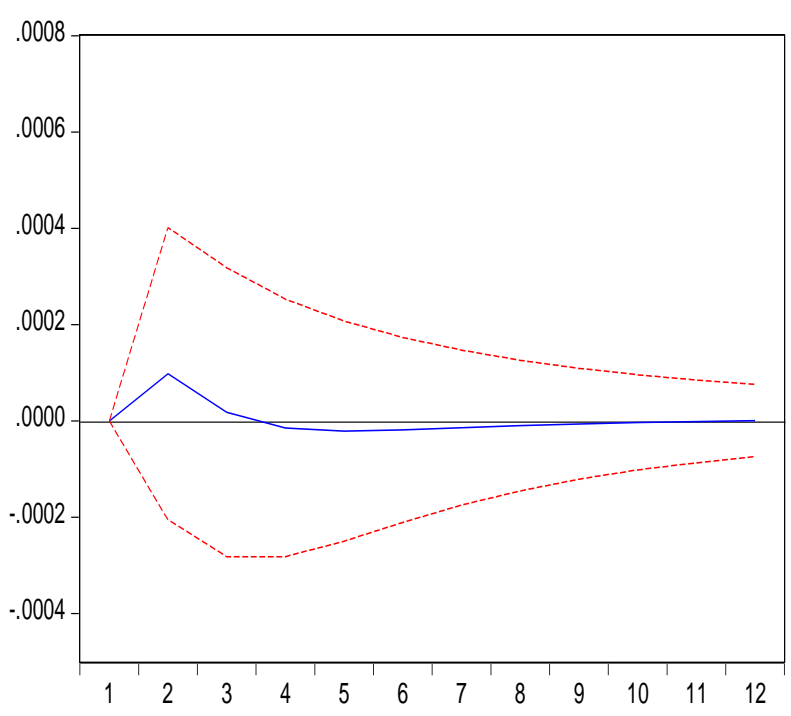

Response of SDDLRGDP to EXCRED: 1984Q1 - 2008Q1

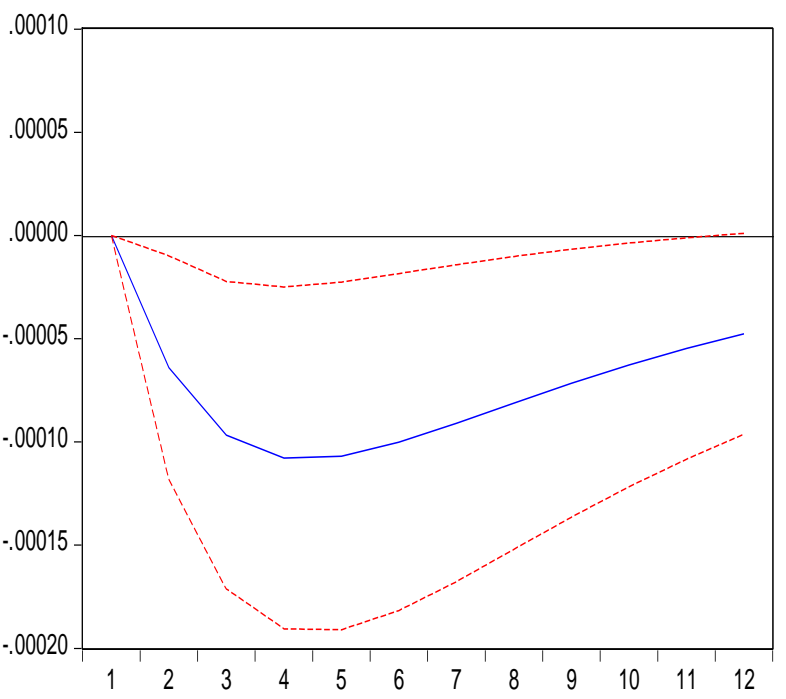

Response of EXCRED to SDDLRGDP: 1954Q3 - 1978Q4

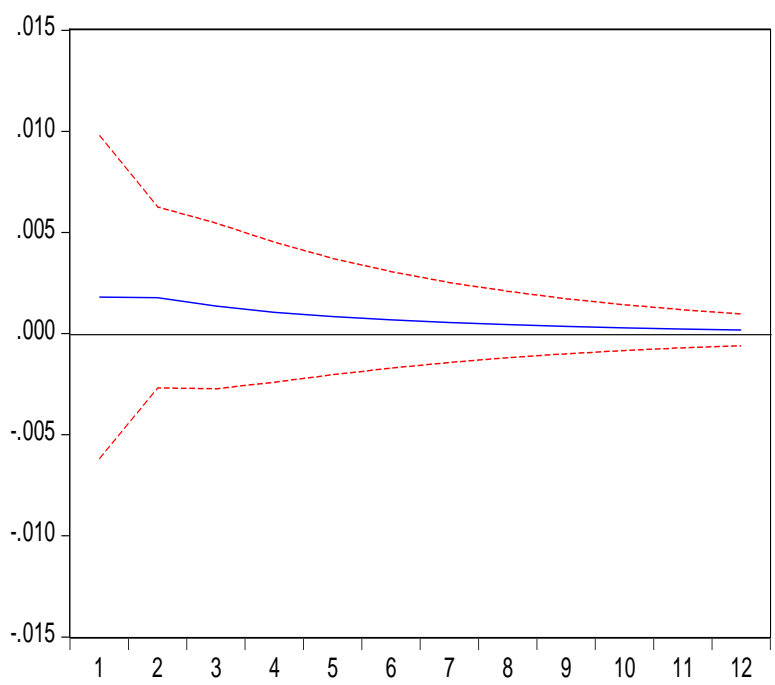

Response of EXCRED to SDDLRGDP: 1984Q1 - 2008Q1

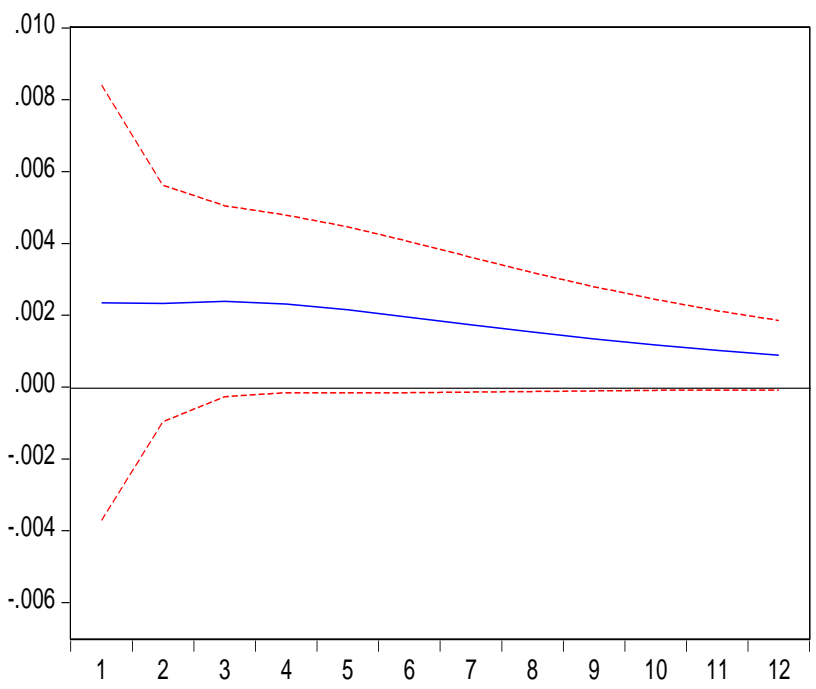




\section{Figure 4 (continued)}

Response of SDDLRGDP to DLFR: 1954Q3 - 1978Q4

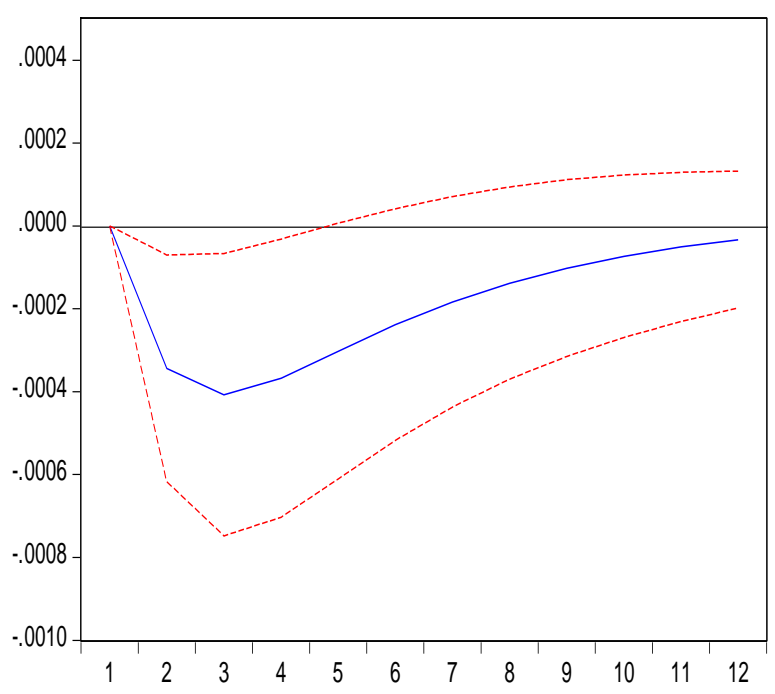

Response of SDDLRGDP to DLFR: 1984Q1 - 2008Q1

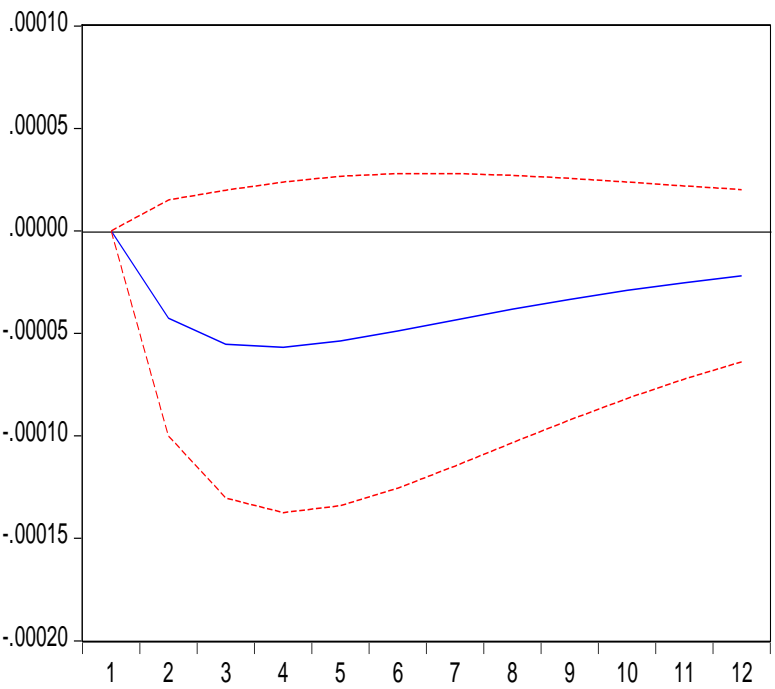

Response of DLFR to SDDLRGDP: 1954Q3 - 1978Q4

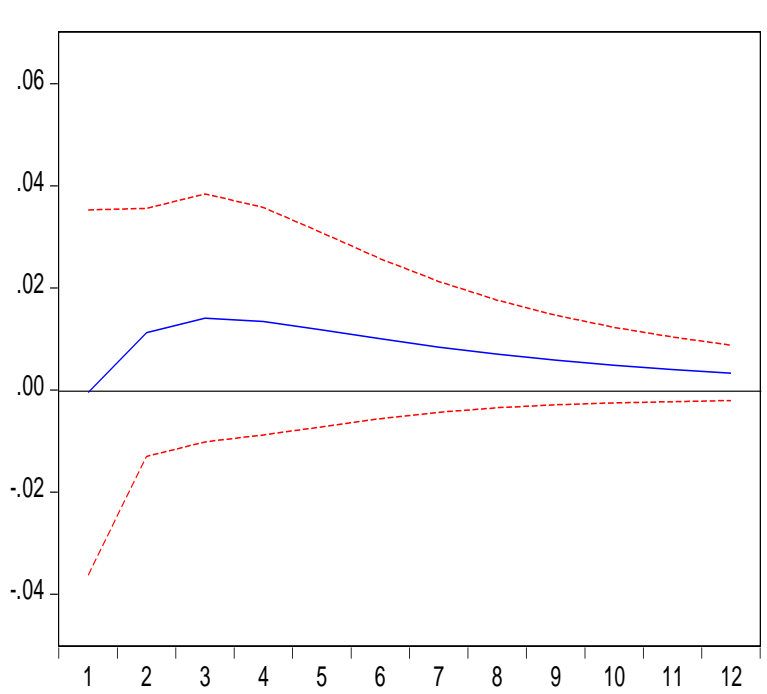

Response of DLFR to SDDLRGDP: 1984Q1 - 2008Q1

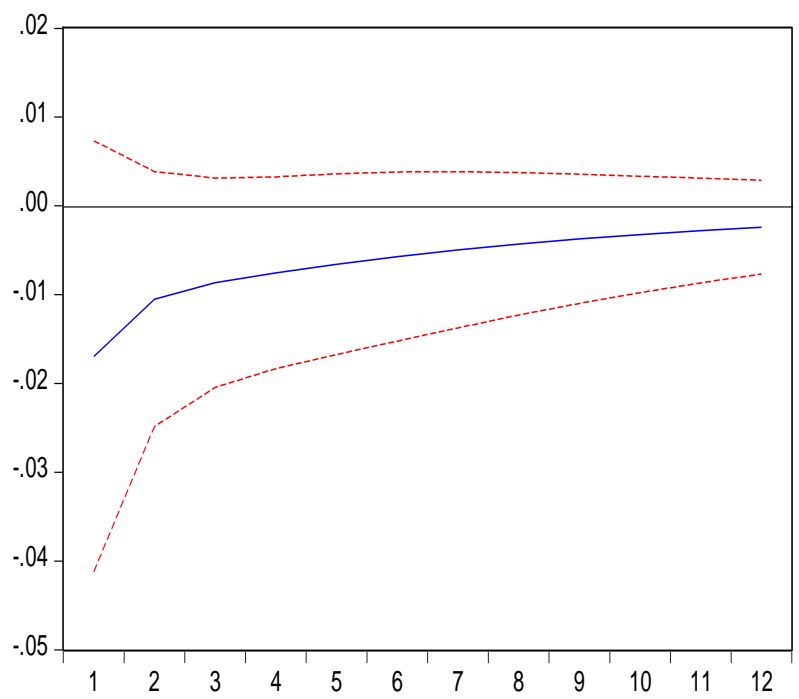




\section{Figure 4 (continued)}

Response of SDDLRGDP to INF: 1954Q3 - 1978Q4

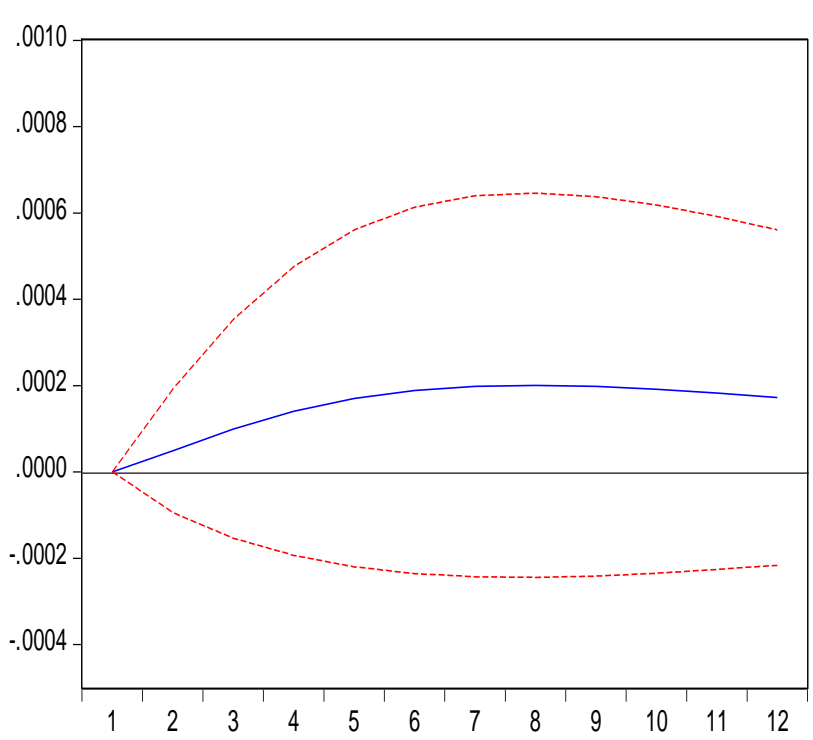

Response of INF to SDDLRGDP: 1954Q3 - 1978Q4

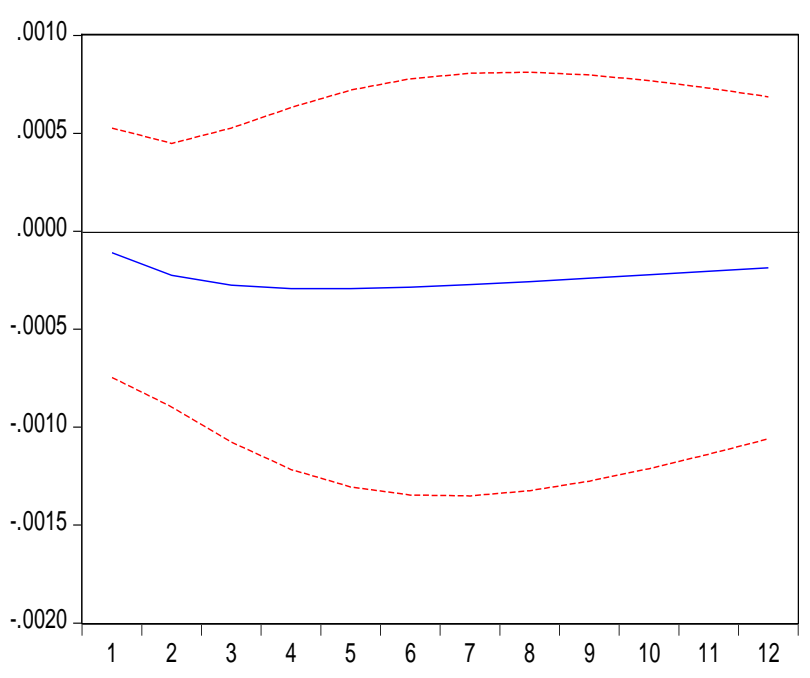

Response of SDDLRGDP to INF: 1984 Q1 - $2008 Q 1$

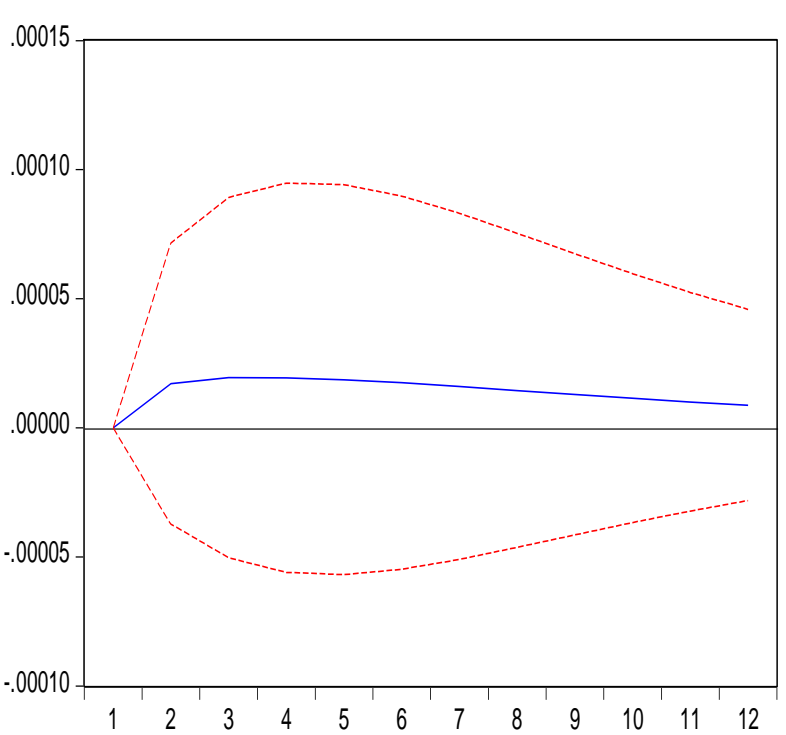

Response of INF to SDDLRGDP: 1984Q1 - $2008 Q 1$

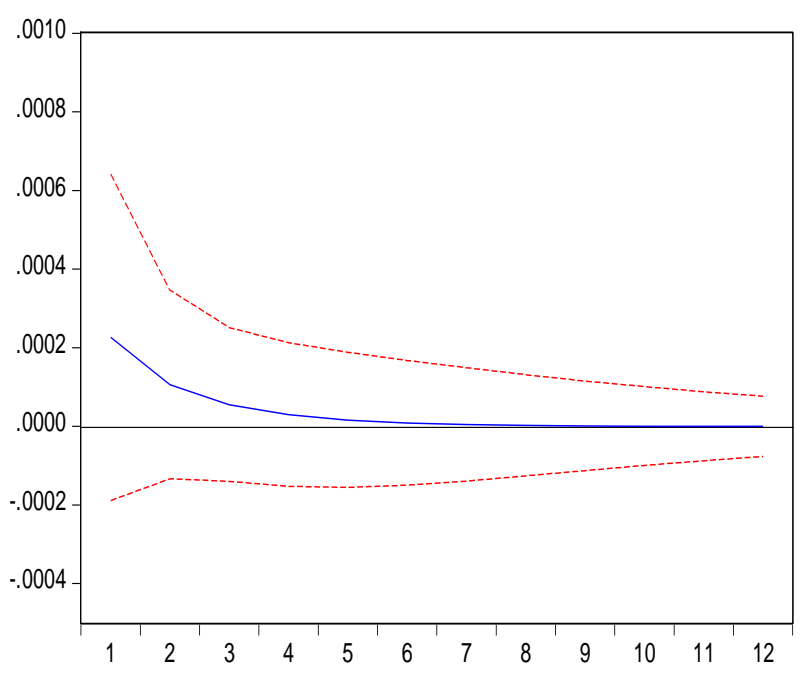




\section{Figure 4 (continued)}

Response of EXCRED to DLFR: 1954Q3 - 1978Q4

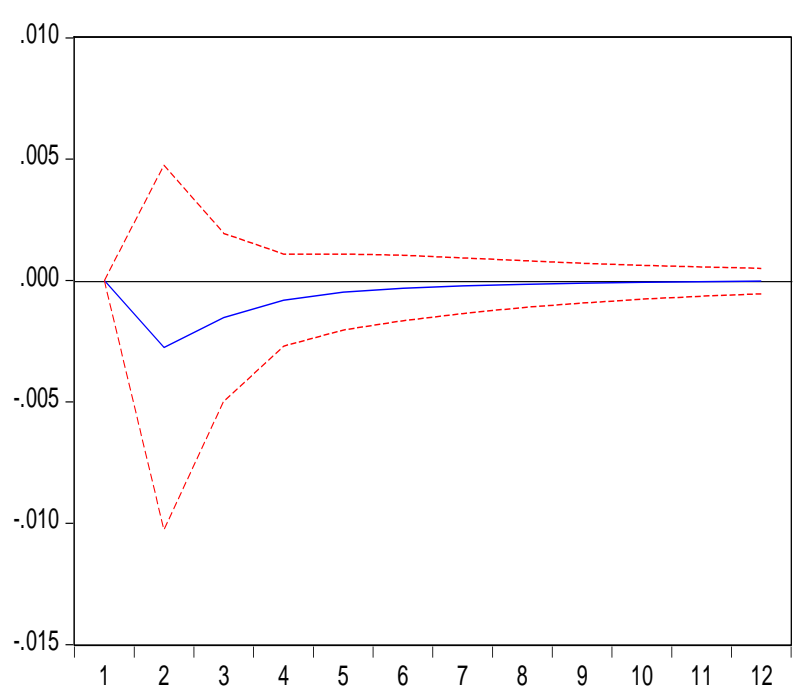

Response of EXCRED to DLFR: 1984Q1 - 2008Q1

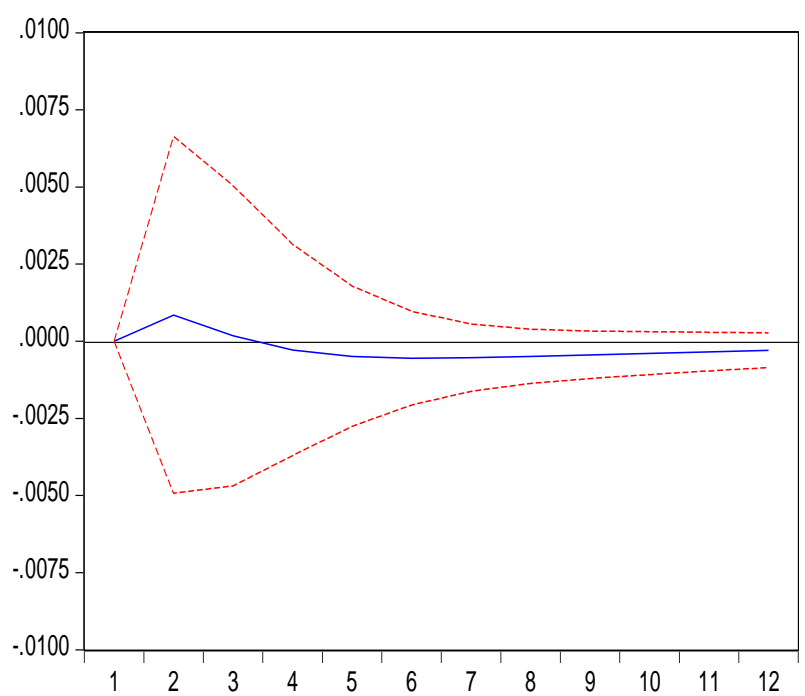

Response of DLFR to EXCRED: 1954 Q3 - 1978Q4

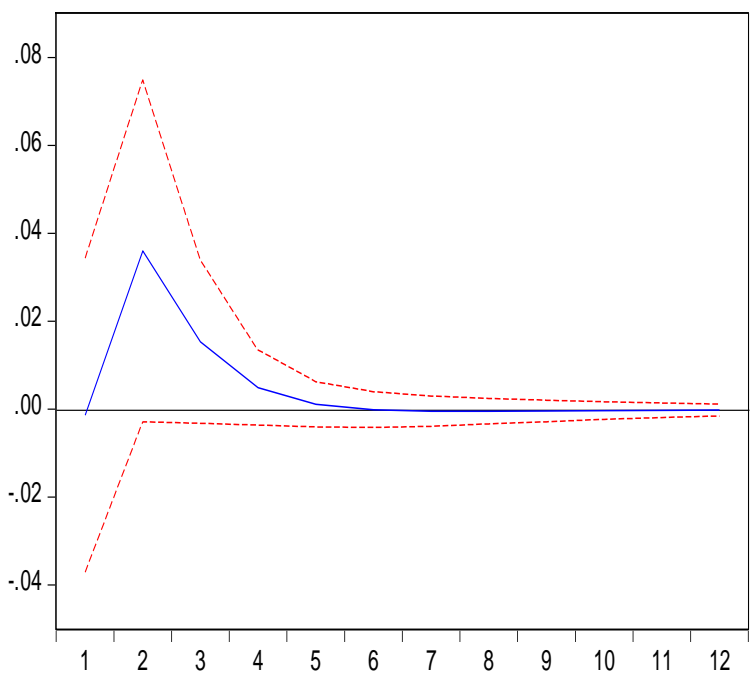

Response of DLFR to EXCRED: 1984Q1 - 2008Q1

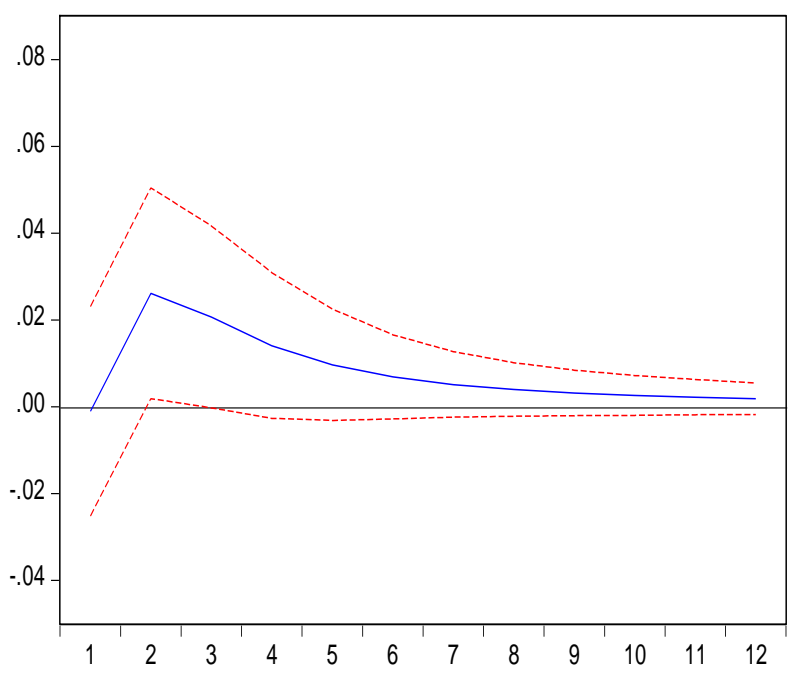




\section{Figure 4 (continued)}

Response of EXCRED to INF: 1954Q3 - 1978Q4

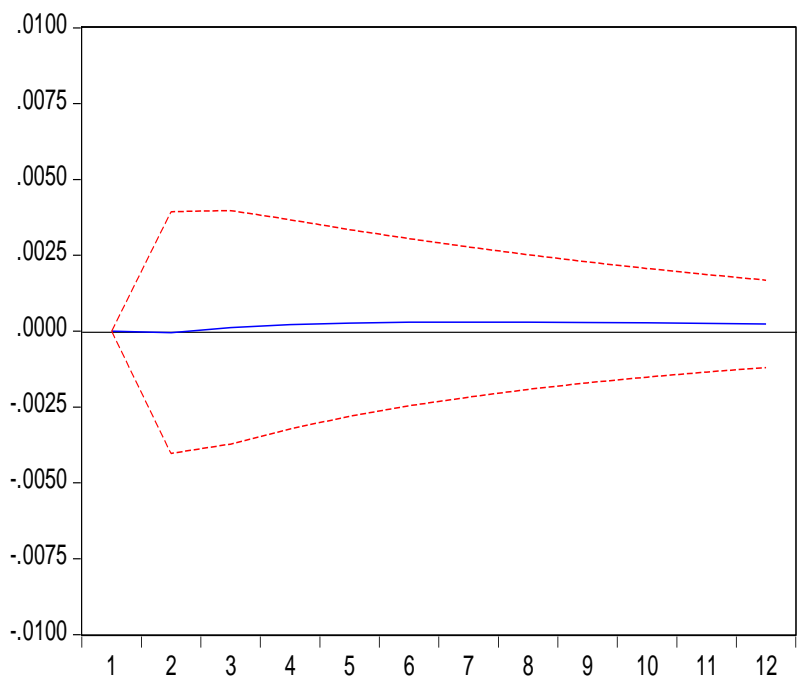

Response of INF to EXCRED: 1954Q3 - 1978Q4

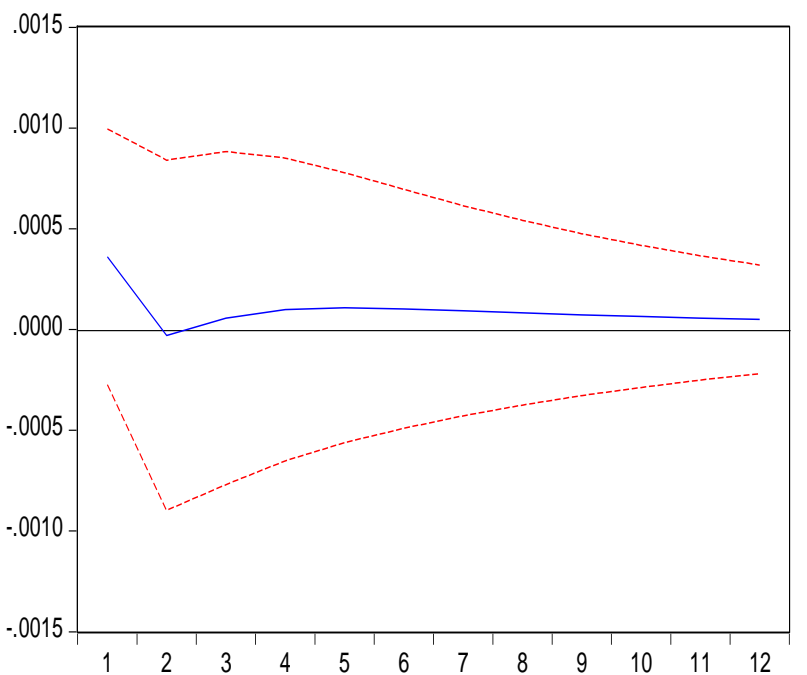

Response of EXCRED to INF: 1984Q1 - 2008Q1

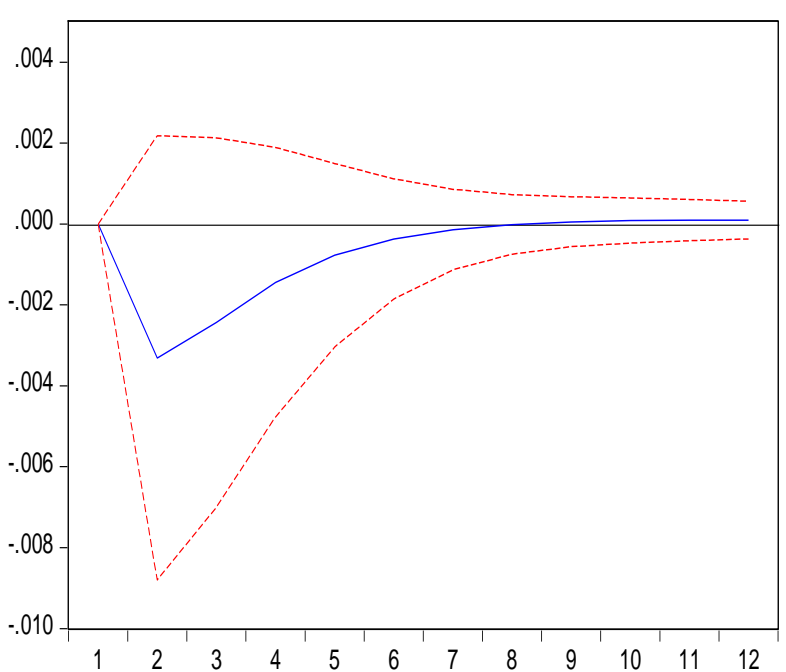

Response of INF to EXCRED: 1984Q1 - 2008Q1

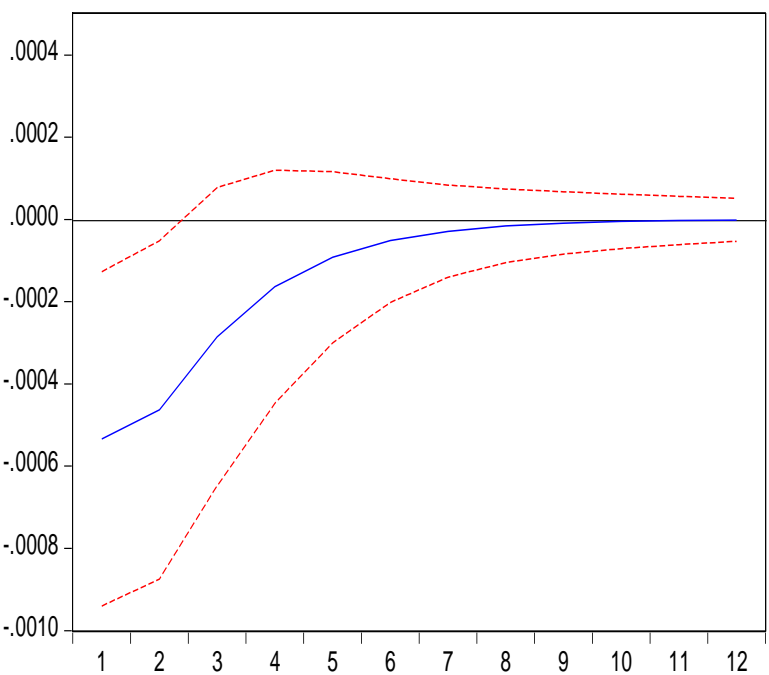




\section{Figure 4 (continued)}

Response of DLFR to INF: 1954Q3 - 1978Q4

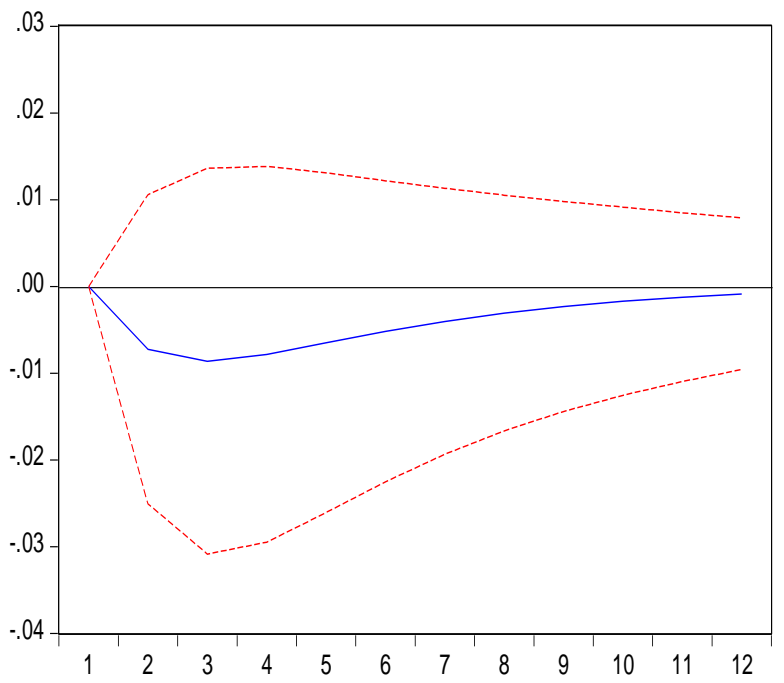

Response of INF to DLFR: 1954Q3 - 1978Q4

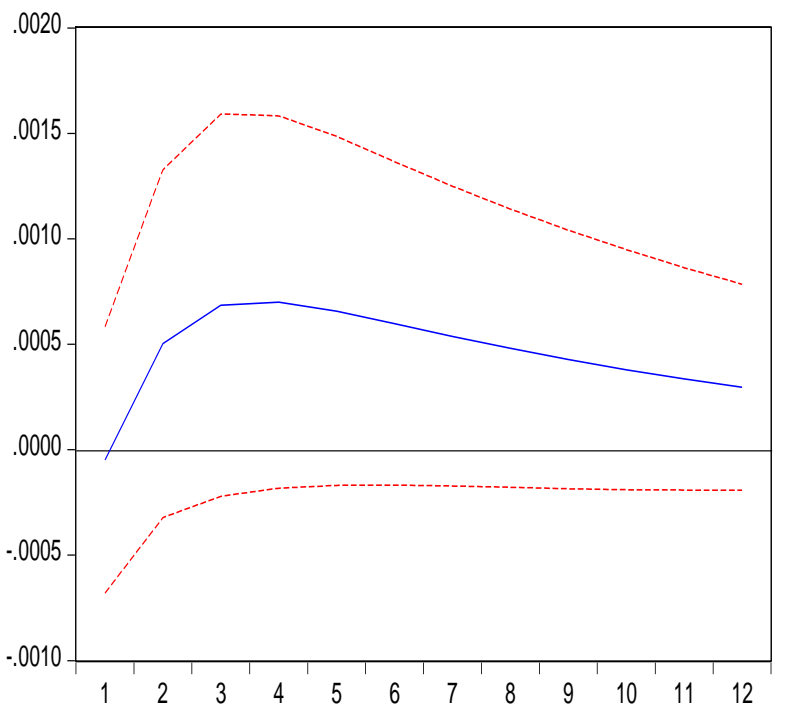

Response of DLFR to INF: 1984Q1 - 2008Q1

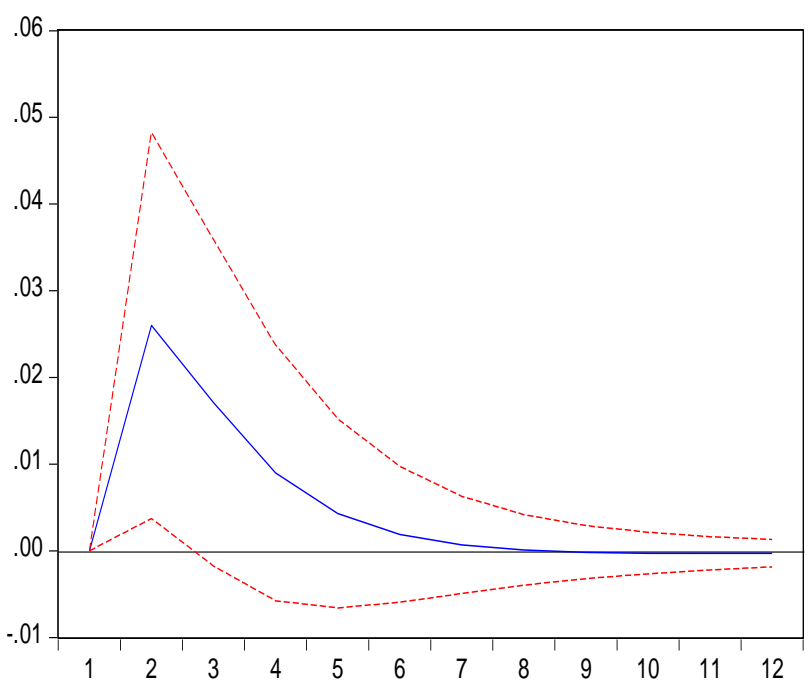

Response of INF to DLFR: 1984Q1 - 2008Q1

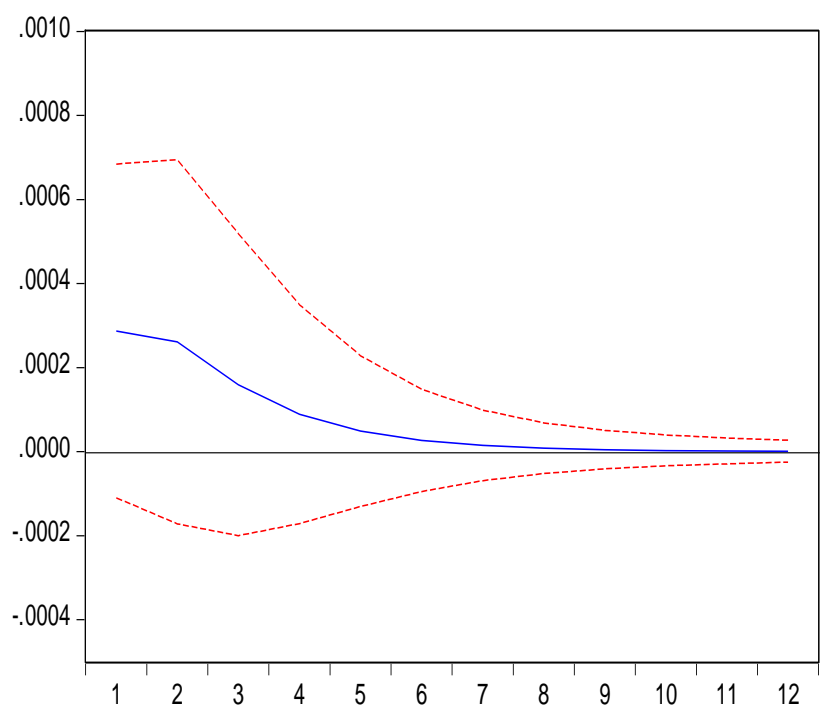

Notes: The impulse responses reflect response to Cholesky one standard deviation innovations \pm 2 s.e. SDDLRGDP reflects output growth volatility demoted as $\sigma$ drrgdp previously. 
Figure 5: Counterfactual Forecast of Output Growth Volatility during the Great Moderation (1984Q1-2008Q1).

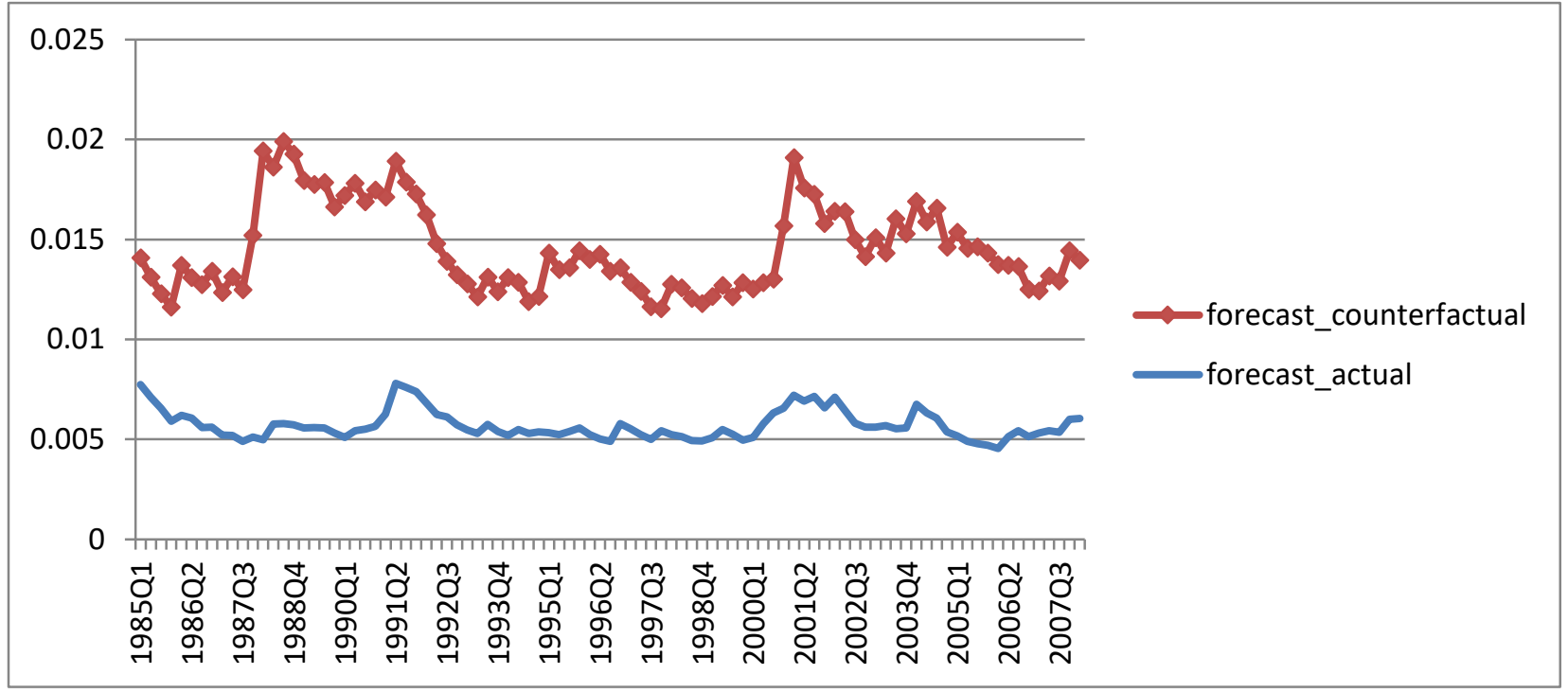

Note: Counterfactual forecasts are constructed by applying during-Great Moderation VAR parameter estimates to pre-Great Moderation variables values, in order to compute output volatility in each quarter. 